\title{
Quantifying the role of paleoclimate and Andean Plateau uplift on river incision
}

\author{
M. Louise Jeffery, ${ }^{1,2}$ Todd A. Ehlers, ${ }^{3,1}$ Brian J. Yanites, ${ }^{1,4}$ and Christopher J. Poulsen ${ }^{1}$ \\ Received 23 June 2012; revised 22 February 2013; accepted 1 March 2013; published 28 May 2013.
}

[1] River incision over geologic timescales can be a valuable indicator of regional surface uplift. However, extracting the timing of surface uplift relative to the onset of incision is complicated by changes in precipitation commensurate with topographic development. Evidence of large-scale river incision on the flanks of the Andean plateau has been cited in support of a rapid and recent surface uplift event. Recent climate modeling studies demonstrate large magnitudes of regional climate change associated with surface uplift of the Andes, which may have influenced river incision processes. Here we present an analysis of mid-Miocene (16 Ma) to present river incision of the southwest Peruvian Ocoña River. A Monte Carlo approach with $\sim 1.6 \times 10^{5}$ different simulations is used to explore the range of surface uplift and paleoclimate histories that are compatible with the modern river profile and geological constraints on the incision timing and magnitude. A range of channel properties, including the erodibility coefficient and erosion threshold, are considered. Results indicate that deep canyon incision on the plateau flanks may not be as diagnostic of rapid surface uplift as previously thought. More specifically, the evolution of the Ocoña River is consistent with local plateau elevations of $1-3 \mathrm{~km}$ at $16 \mathrm{Ma}$ and either a steady or punctuated uplift of 1.5-3.5 km since then. The range of acceptable uplift histories is sensitive to the long-term magnitude and temporal evolution of precipitation. Similar paleoprecipitation changes are expected to have modified river profile evolution elsewhere in the Andes.

Citation: Jeffery, M. L., T. A. Ehlers, B. J. Yanites, and C. J. Poulsen (2013), Quantifying the role of paleoclimate and Andean Plateau uplift on river incision, J. Geophys. Res. Earth Surf., 118, 852-871, doi:10.1002/jgrf.20055.

\section{Introduction}

[2] Bedrock river profiles are sensitive to tectonics, climate, and the internal dynamics of rivers, such as river capture [Roe et al., 2003; Whipple, 2009]. Analysis of modern river profiles is a useful tool for quantifying interactions of these processes over million year timescales. For example, records of river incision have been used to infer discrete uplift events and large-scale changes in catchment geometry [e.g., Attal et al., 2008; Clark et al., 2004; Crosby and Whipple, 2006; Duvall et al., 2004; Kirby and Whipple, 2001; Snyder et al., 2000; Whipple and Tucker, 1999; Whittaker et al., 2008; Yanites et al., 2010]. Constraining the timing of surface uplift is an important but challenging goal in the study of orogen development. Geological

Additional supporting information may be found in the online version of this article.

${ }^{1}$ Department of Earth and Environmental Sciences, University of Michigan, Ann Arbor, Michigan, USA.

${ }^{2}$ Now at Potsdam Institute for Climate Impact Research, Potsdam, Germany.

${ }^{3}$ Department of Geosciences, Universität Tübingen, Tübingen, Germany.

${ }^{4}$ Now at Department of Geological Sciences, University of Idaho, Moscow, Idaho, USA.

Corresponding author: M. L. Jeffery, Potsdam Institute for Climate Impact Research, Potsdam, D-14412, Germany. (louisej@umich.edu)

(C)2013. American Geophysical Union. All Rights Reserved. 2169-9003/13/10.1002/jgrf.20055 constraints on the timing and magnitude of river incision can constrain surface uplift because a change in relative base level (e.g., surface uplift) can drive incision of a comparable depth. However, precipitation can also play a significant role in shaping the landscape by modifying river discharge and erosion [Roe et al., 2003; Whipple, 2009; Willett, 1999]. The spatial distribution of precipitation modifies the shape of steady state longitudinal river profiles [Roe et al., 2002; $W u$ et al., 2006], and an increase in mean annual precipitation is expected to drive river incision [Wobus et al., 2010; Zaprowski et al., 2005]. Regional climate can be strongly modified by mountain belt development and surface uplift [e.g., Kutzbach et al., 1989; Roe, 2005]. Consequently, tectonics and climate are interdependent controls on the development of fluvial landscapes.

[3] The surface uplift history of the central Andes is unresolved, with end-member models that include (1) a "slow and steady" uplift of $\sim 4 \mathrm{~km}$ since $\sim 40 \mathrm{Ma}$ and (2) a "punctuated" uplift with a rapid rise of $\sim 2.5 \mathrm{~km}$ between 10 and $6 \mathrm{Ma}$ [Barnes and Ehlers, 2009; Ehlers and Poulsen, 2009; Hoke and Garzione, 2008]. Deeply incised canyons on both flanks of the Central Andean Plateau have the potential to help distinguish between these two models. Estimates of incision magnitudes have been derived from a variety of techniques including thermochronometry, paleosurface degradation, and analysis based on river profile knickpoint migration [Barke and Lamb, 2006; Barnes et al., 2006; Farias et al., 2008; Garzione et al., 2008; Gubbels et al., 
1993; Hartley et al., 2007; Hoke et al., 2007; Kennan et al., 1997; Kober et al., 2006; McQuarrie et al., 2008a; McQuarrie et al., 2008b; Schildgen et al., 2010; Schildgen et al., 2007; Schildgen et al., 2009a; Schildgen et al., 2009b; Schlunegger et al., 2006; Simpson, 2004; Walcek and Hoke, 2012]. Incision magnitudes range from 0.25 to $3 \mathrm{~km}$, and in most cases, incision began in the late Miocene (10-5 Ma) suggesting a contemporaneous, regional-scale driver such as surface uplift of the plateau. The largest incision estimates are for the Maran-Cotahuasi-Ocoña catchment (hereafter, Ocoña) in southwestern Peru $\left(14^{\circ} \mathrm{S}-16^{\circ} \mathrm{S}\right.$, Figure 1a) where thermochronometry and ${ }^{40} \mathrm{Ar} /{ }^{39} \mathrm{Ar}$-dated, valley-filling, ignimbrite flows indicate $>2.5 \mathrm{~km}$ incision since $\sim 9 \mathrm{Ma}$ [Gunnell et al., 2010; Schildgen et al., 2010; Schildgen et al., 2007; Schildgen et al., 2009b; Thouret et al., 2007]. In many cases, a distinction between different plateau surface uplift models cannot be made based on incision timing and magnitudes because the observations can fit either model within error [Barnes and Ehlers, 2009]. Incision depths and rates in the Ocoña catchment require surface uplift of $\sim 2.4-3 \mathrm{~km}$ since $14 \mathrm{Ma}$ [Schildgen et al., 2009a].

[4] However, recently it has been suggested that the late Miocene incision was not driven by rapid surface uplift, but rather by an increase in precipitation rates [Barnes and Ehlers, 2009; Ehlers and Poulsen, 2009]. At plateau elevations greater than $\sim 50 \%$ of the modern, convective precipitation is initiated on the eastern Andean flanks [Insel et al., 2010; Poulsen et al., 2010], which also results in higher precipitation rates in the headwaters of larger catchments on the western flanks. Previous studies have demonstrated that modern river profiles, catchment-scale erosion rates, and drainage basin morphology reflect spatial variations in modern precipitation rates [Abbuehl et al., 2011; Bookhagen and Strecker, 2012; Garcia et al., 2011; Schlunegger et al., 2011] suggesting that regional precipitation patterns exert a control on the modern fluvial landscape [Strecker et al., 2009]. However, the influence of climate change in determining the timing and magnitude of river incision on million year timescales has not been quantified for this region. Furthermore, it is not clear whether increased precipitation could induce sufficient erosion to account for late Miocene river incision.

[5] In this study, a one-dimensional (1-D) river incision model is developed to simulate the incision history of the Ocoña canyon (Figure 1a). A Monte Carlo search process is used to identify the range of surface uplift conditions that are consistent with geological observations and simulated changes in regional climate [Ehlers and Poulsen, 2009; Insel et al., 2010]. The Monte Carlo search approach is also used to account for a range of different possible erosion mechanisms and river channel properties.

\section{Geologic and Climatic Setting}

[6] The Andes Mountains formed as the result of Nazca Plate subduction beneath the South American Plate. Deformation in the central Andes began $\sim 60-40 \mathrm{Ma}$ [DeCelles and Horton, 2003; McQuarrie et al., 2005], accelerated $\sim 25 \mathrm{Ma}$, and has since migrated eastward from the Altiplano Plateau into the foreland fold-and-thrust belt [Barnes et al., 2008; McQuarrie, 2002]. In southern Peru, crustal shortening of $\sim 123 \mathrm{~km}$ has been recorded on the eastern flanks [Gotberg et al., 2010]. In contrast, shortening rates on the western flanks are much lower, although highangle reverse faults accommodated shortening prior to $\sim 8 \mathrm{Ma}$ [Farias et al., 2005; Muñoz and Charrier, 1996; Victor, 2004], and there is geomorphic evidence for active deformation on smaller contractile structures that continues to the present [Hall et al., 2012]. In the Ocoña catchment, late Cenozoic activity on the Iquipi fault accommodated left lateral motion prior to 25-15 Ma [Roperch et al., 2006] and a later component of northside down motion ( 100-200 m) [Schildgen et al., 2009a]. Plateau relief on the western flank is therefore attributed to a crustal-scale monocline [Hall et al., 2012; Isacks, 1988; Schildgen et al., 2009a; Wörner et al., 2002]. A smooth topographic ramp links the active western cordillera to an $\sim 1 \mathrm{~km}$ high escarpment at the Pacific Coast. This topographic ramp is dissected to depths of up to $3.5 \mathrm{~km}$ by the Ocoña Canyon (Figure 1).

[7] The Ocoña River cuts through middle to late Miocene ignimbrites, the Cenozoic Moquegua group, and PaleozoicMesozoic igneous and metamorphic basement in its deepest reaches. Deposition of the lower Moquegua group occurred -50-30 Ma [Decou et al., 2011; Roperch et al., 2006]. This group consists of predominantly terrestrial red mudstones, siltstones, and sandstones with intercalated conglomerates that were deposited in endorheic basins. Since $\sim 30 \mathrm{Ma}$, a clastic wedge of alluvial, deltaic, and debris flow deposits of the upper Moquegua group formed on the western Andean flanks with some upper Oligocene marine deposits at the base [Roperch et al., 2006]. Decou et al. [2011] reported an increase in the energy of depositional environment and a transition from distal to more proximal sources through the Cenozoic. In the region of the Ocoña canyon, sedimentary deposition ceased $\sim 16-14 \mathrm{Ma}$ and was capped by one or more regionally extensive ignimbrites between 16.2 and 13.2 Ma [Schildgen et al., 2007; Schildgen et al., 2009a; Thouret et al., 2007]. The base of this ignimbrite forms a regional paleosurface (Figure 1b) [Schildgen et al., 2007; Thouret et al., 2007] that we use to constrain the amount of incision since the cessation of deposition of the upper Moquegua group.

[8] Results from multiple thermochronometry studies combined with dates of valley-filling ignimbrite and basaltic andesite lava flows provide estimates on the timing of canyon incision. Thermal modeling constrained by apatite and zircon (U-Th)/He data shows that canyon incision into the 16-14 Ma paleosurface began 11-8 Ma and ended 5-2 Ma [Schildgen et al., 2010; Schildgen et al., 2007; Schildgen et al., 2009b]. The modeled delay between paleosurface formation and onset of deep incision is further supported by observations of $\sim 9 \mathrm{Ma}$ ignimbrite flows that fill up to $\sim 600 \mathrm{~m}$ deep paleochannels in the neighboring Caravelí valley [Thouret et al., 2007]. Furthermore, dated volcanic deposits on the valley floor and walls provide constraints on the incision history (Figure 1b). These deposits show that a minimum of $75 \%$ of the incision had occurred by $\sim 4 \mathrm{Ma}$ near the confluence of the Maran and Cotahuasi Rivers (Figure 1, sample 5) [Thouret et al., 2007] and 90-100\% of incision was complete by $2 \mathrm{Ma}$ (Figure 1, samples 1-4) [Schildgen et al., 2007; Schildgen et al., 2009b; Thouret et al., 2007]. In contrast to the rapid $\left(0.1-1 \mathrm{~mm} \mathrm{yr}^{-1}\right)$ incision of the canyon, denudation rates of interfluve surfaces constrained by (U-Th)/He apatite cooling ages, cosmogenic exposure dating, and sediment budgets 

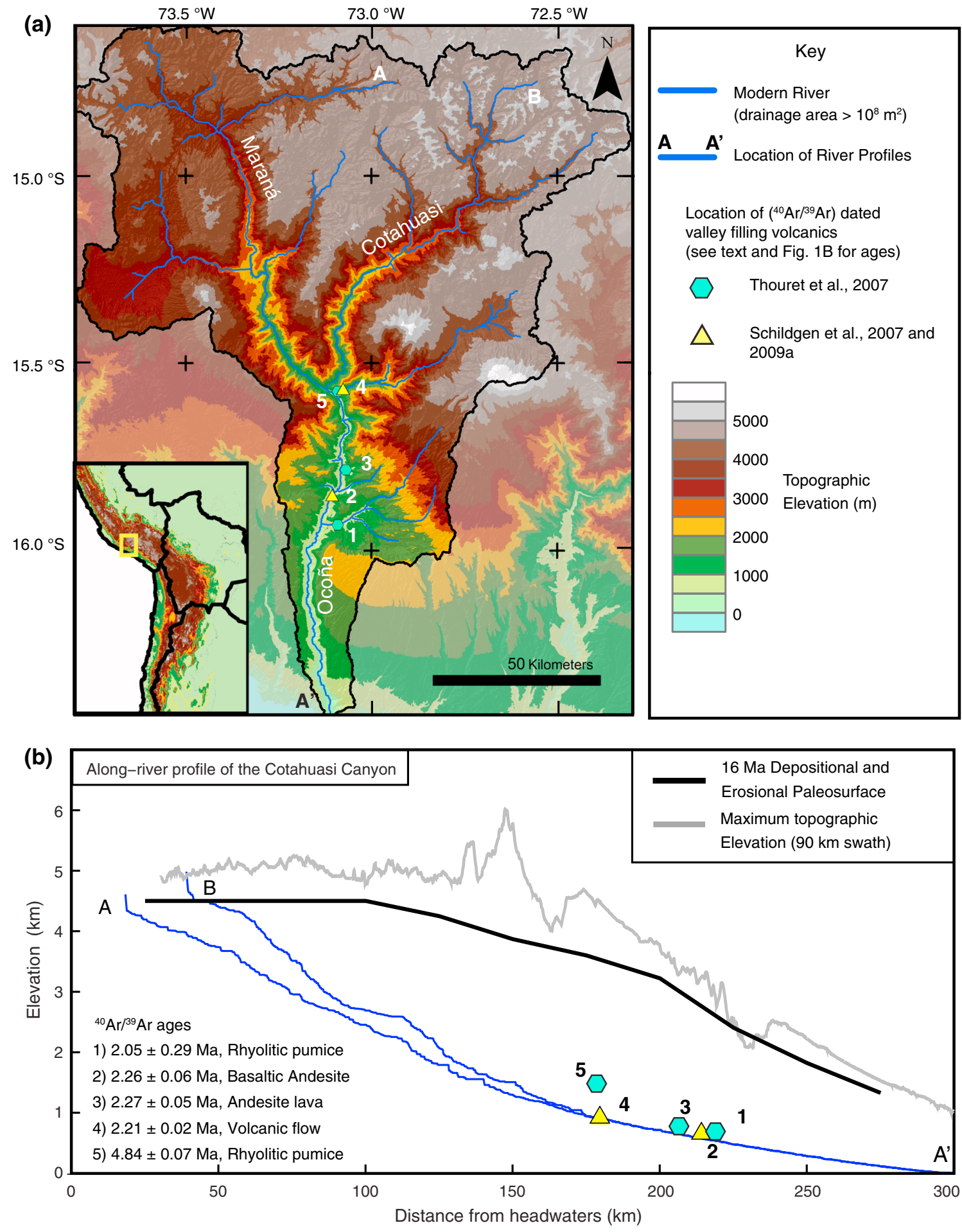

Figure 1. (a) Modern topography of the Ocoña catchment and (inset) its location on the western flanks of the northern Altiplano. Locations of dated volcanic deposits that provide stratigraphic constraints on the timing of incision are indicated by yellow triangles [Schildgen et al., 2007, 2009a] and green hexagons [Thouret et al., 2007]. Locations of river profiles shown in Figure $1 \mathrm{~b}$ are indicated by A, $\mathrm{A}^{\prime}$, and $\mathrm{B}$. (b) Longitudinal river profiles corresponding to the western (A) and eastern (B) branches of the river (blue), a $90 \mathrm{~km}$ wide swath of maximum topography centered on the canyon mouth (gray), and modern elevation of the $16 \mathrm{Ma}$ paleosurface (black, see text and the auxiliary material for details). Profiles were extracted from a filled $30 \mathrm{~m}$ ASTER DEM.

are as low as $0.001 \mathrm{~mm} \mathrm{yr}^{-1}$ in northern Chile [Kober et al., 2007], and up to $\sim 0.05 \mathrm{~mm} \mathrm{yr}^{-1}$ in the Ocoña region [Schildgen et al., 2007].
[9] On the western Andean flanks in southern Peru, modern mean annual precipitation rates increase from $<0.1 \mathrm{~m} \mathrm{yr}^{-1}$ at the coast to $\sim 1 \mathrm{~m} \mathrm{yr}^{-1}$ at the plateau 


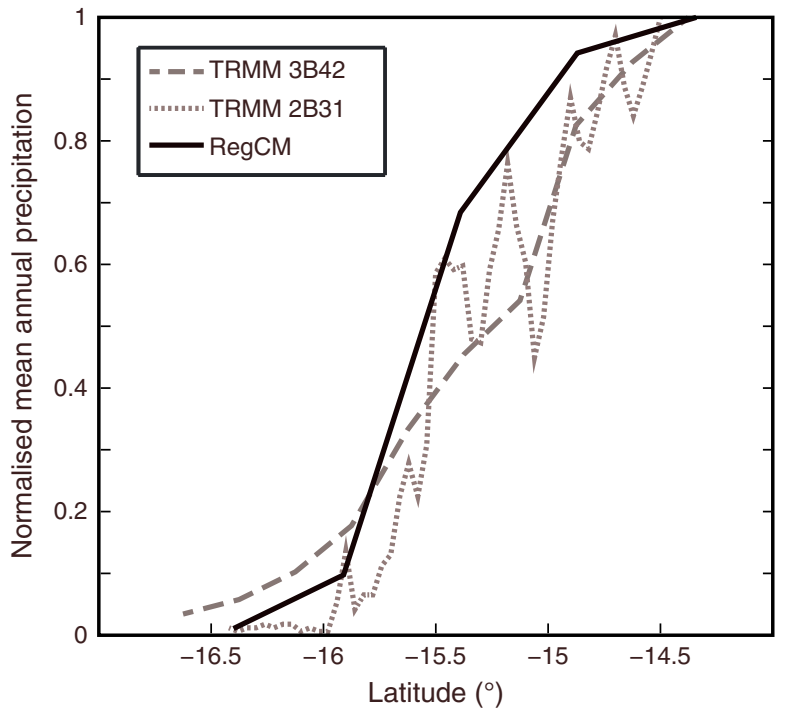

Figure 2. Normalized modern mean annual precipitation rates across the Ocoña canyon from two Tropical Rainfall Measuring Mission (TRMM) products [Bookhagen and Strecker, 2008; Huffman et al., 2007] and the RegCM model results used in this study. All data sets are normalized by the maximum value in the region to enable comparison of spatial distributions.

margin (Figure 2) [Bookhagen and Strecker, 2008; Houston and Hartley, 2003; Huffman et al., 2007]. Hyperarid conditions at the coast have been attributed to (1) the subtropical location, (2) blocking of moisture by the Andes, and (3) the cold Humboldt Current that creates a temperature inversion along the coast and traps moisture below $\sim 800 \mathrm{~m}$ [Houston and Hartley, 2003]. In the present climate, moisture that reaches the headwaters of the Ocoña catchment is predominantly the result of spillover of summertime convective precipitation from air masses that originate in the Amazon basin and cross the plateau [Garreaud, 1999; Garreaud et al., 2003; Houston and Hartley, 2003]. Climate modeling studies have demonstrated that the amounts of convective precipitation increase with increasing Andean elevation [Campetella and Vera, 2002; Ehlers and Poulsen, 2009; Insel et al., 2010; Lenters and Cook, 1995; Poulsen et al., 2010]. The precipitation response to plateau elevation is spatially variable and displays a threshold behavior; convective precipitation increases when plateau elevations exceed $\sim 70 \%$ [Poulsen et al., 2010]. Other than Andean uplift, significant drivers of regional climate change during the late Cenozoic include global cooling, Amazonian seaway incursions [Frailey et al., 1988; Rasanen et al., 1995], and onset of the Humboldt Current along the west coast of South America [Houston and Hartley, 2003]. Paleoclimate simulations indicate that global cooling, through lowering of atmospheric $\mathrm{CO}_{2}$, and Amazonian seaway incursions have had little effect on precipitation rates in southwestern Peru [Jeffery et al., 2012]. This study therefore focuses on climate change in response to increased surface elevation and the resulting effect on fluvial discharge and erosion.

\section{Methods: Simulating River Profile Evolution With a Monte Carlo Search Approach}

[10] In this study, we identify the range of surface uplift conditions that are consistent with geologic and geomorphic observations and quantify the importance of precipitation to the river incision history. This range is determined by simulating the evolution of the Ocoña River profile using a 1-D river profile evolution model. All simulations are initiated at $16 \mathrm{Ma}$ when a regionally extensive paleosurface formed (Figures $1 \mathrm{~b}$ and $3 \mathrm{a}$ ) and run forward to the present day. Many of the parameters that describe river behavior are underconstrained for both the modern and past Ocoña River. To account for a range of all possible combinations of plausible incision parameters and boundary conditions, a Monte Carlo search method is used. This resulted in a total of $1.64 \times 10^{5}$ river profile evolution scenarios. Each simulated scenario is evaluated using the shape of the modern river profile (Figure 1b) and geological constraints on the timing and evolution of incision. Results are presented in terms of surface uplift histories that fit these constraints. In this section, we describe the model setup in detail. First, the basic model equations are described and free parameters identified. Second, the initial and boundary conditions for the Ocoña catchment are outlined. Third, the geological constraints used to evaluate the model output are defined. Finally, the model sensitivity to the assumptions used is evaluated.

\subsection{Stream Power-Based River Incision Model}

[11] The river incision model calculates the elevation profile of a riverbed through time. Riverbed elevations are a function of relative rates of uplift $(U)$ and incision. River incision is calculated following a commonly used, detachment limited, shear stress-based erosion law [Howard et al., 1994; Seidl and Dietrich, 1992; Snyder et al., 2000; Whipple and Tucker, 1999]. Active incision occurs only when the basal shear stress exceeds a critical shear stress required to move sediment. River profile evolution is therefore described by the conditional equations:

$$
\begin{gathered}
\frac{\mathrm{d} h}{\mathrm{~d} t}=U-k_{b}\left(\tau_{b}-\tau_{c}\right)^{a} \tau_{b}>\tau_{c} \\
\frac{\mathrm{d} h}{\mathrm{~d} t}=U \quad \tau_{b} \leq \tau_{c}
\end{gathered}
$$

where $\mathrm{d} h / \mathrm{d} t\left(\mathrm{~m} \mathrm{yr}^{-1}\right)$ is the change in elevation of the riverbed through time, $U\left(\mathrm{~m} \mathrm{yr}^{-1}\right)$ is the rock uplift rate, $\tau_{b}(\mathrm{~Pa})$ is the basal shear stress, $\tau_{c}(\mathrm{~Pa})$ is the critical shear stress, $a$ is a dimensionless constant dependent on the physical process of erosion, and $k_{b}\left(\mathrm{~m}^{(a+1)} \mathrm{yr}^{(2 a-1)} \mathrm{kg}^{(-a)}\right)$ is an erosivity constant that incorporates erosion process and bedrock lithology and strength. Theoretically determined values for $a$ range between 1 and $7 / 2$ based on different incision mechanisms [Foley, 1980; Hancock et al., 1998; Howard and Kerby, 1983; Whipple et al., 2000]. In all experiments presented here, a value of $a=3 / 2$ is chosen in accordance with a stream power-based incision law in which the rate of incision is proportional to the rate of energy dissipation per unit bed area [Howard et al., 1994; Seidl and Dietrich, 1992; Whipple and Tucker, 1999]. Sensitivity experiments verified that the range of uplift histories found does not depend on the choice of $a$ (see section 5.3.3). Empirically determined values of the dimensional erosion coefficient $k_{b}$ vary over several orders of magnitude [Stock and Montgomery, 1999], and the units of $k_{b}$ are dependent on the value of $a$. $k_{b}$ is a free parameter in the Monte Carlo search (see Table 1 for range of values) because it exerts a strong control on the 

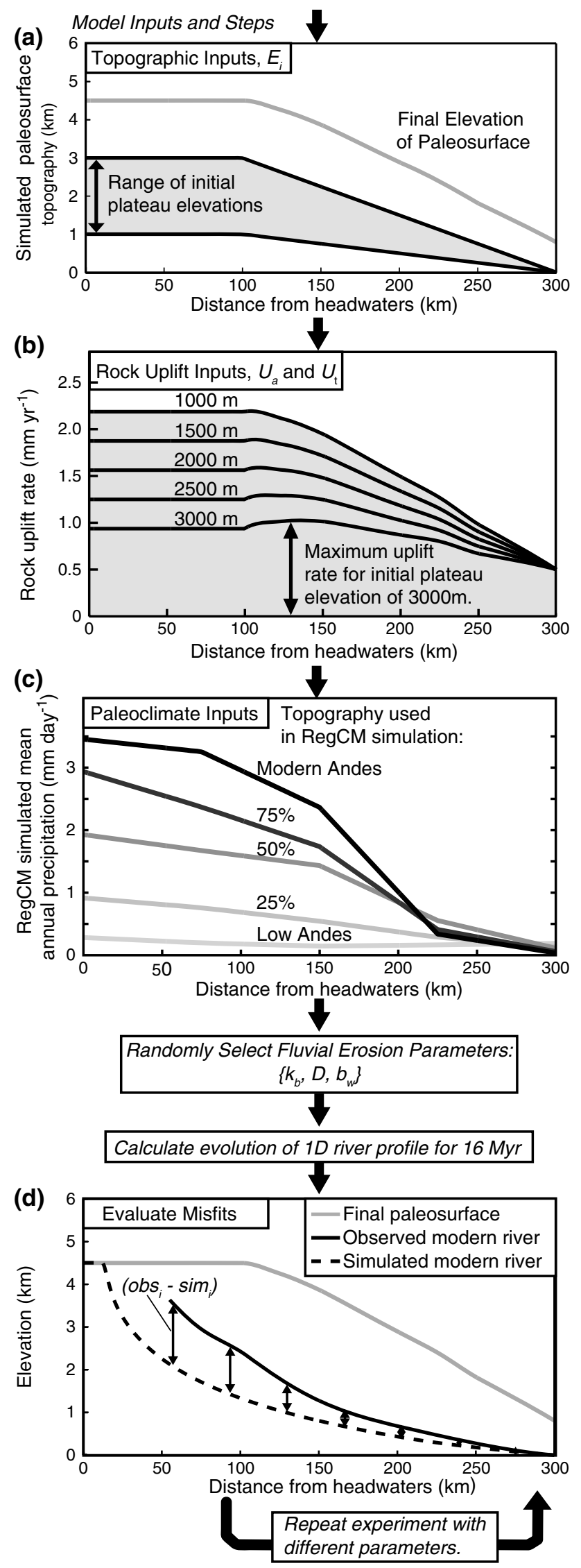

magnitude of incision rates and is dependent on multiple, under-constrained properties, such as bedrock erodibility.

[12] The basal shear stress $\left(\tau_{b}\right)$, and therefore the potential for erosion, is dependent on channel flow properties according to

$$
\tau_{b}=\rho_{w} C_{f}^{\frac{1}{3}} g^{\frac{2}{3}}\left(\frac{Q}{W}\right)^{\frac{2}{3}} S^{\frac{2}{3}}
$$

where $\rho_{w}\left(\mathrm{~kg} \mathrm{~m}^{-3}\right)$ is the density of water, $C_{f}$ is the DarcyWeisbach dimensionless friction factor, $g\left(\mathrm{~m} \mathrm{yr}^{-2}\right)$ is gravitational acceleration, $Q\left(\mathrm{~m}^{3} \mathrm{yr}^{-1}\right)$ is channel discharge, $W$ (m) is channel width, and $S\left(\mathrm{~m} \mathrm{~m}^{-1}\right)$ is the local channel bed slope, which is an approximation for the channel surface slope [Snyder et al., 2000; Tucker and Slingerland, 1997]. Values assigned to parameters $\rho_{w}, C_{f}$, and $g$ are listed in Table 2. Channel slope is calculated by differencing the elevation of the local node with that of the downstream node.

[13] Parameterization of the discharge terms $(Q$ and $W)$ in equation (2) determines the shape of the steady state river profile and the river response to changes in discharge. In this study, we explicitly account for nonuniform precipitation distributions within the catchment (see section 3.2) and the dependence of channel width on discharge [Montgomery and Gran, 2001; Yanites and Tucker, 2010]. Total discharge at a point on the profile is assumed to be proportional to the integral of upstream drainage area and precipitation rates. Upstream drainage area, $A\left(\mathrm{~m}^{2}\right)$, is prescribed following Hack's law [Hack, 1957]

$$
A=k_{a} x^{h}
$$

where $k_{a}\left(\mathrm{~m}^{2-\mathrm{h}}\right)$ is a dimensional constant and $h$ (dimensionless) is the reciprocal of the Hack exponent. Appropriate values of $k_{a}=130 \mathrm{~m}^{1 / 2}$ and $h=1.5$ were determined for the Ocoña catchment from a $30 \mathrm{~m}$ Advanced Spaceborne Thermal Emission and Reflection Radiometer (ASTER) digital elevation model (DEM) [Ministry of Economy, Trade and Industry (METI) and NASA, 2001]. The relatively low value of $h$ for this catchment [Hack, 1957; Rigon et al.,

Figure 3. The Monte Carlo search process incorporates the following model set up and evaluation steps. (a) Initial and final paleosurface elevations. Initial plateau elevation is randomly selected from discrete $0.5 \mathrm{~km}$ intervals between 1.0 and $3.5 \mathrm{~km}$. (b) Range of rock uplift rates for each initial plateau elevation. Rock uplift occurs in two stages with rates that together raise the initial surface to the modern observed paleosurface elevation (Figure 3a). Typical uplift rates are $\sim 0.1-0.2 \mathrm{~mm} \mathrm{yr}^{-1}$. (c) Precipitation rates simulated by RegCM for plateau elevations at $100 \%, 75 \%, 50 \%$, and $25 \%$ of modern elevations and a "Low Andes" scenario in which maximum elevation is $250 \mathrm{~m}$ [Ehlers and Poulsen, 2009; Insel et al., 2010]. In river incision simulations, precipitation rates are tied to plateau elevations and interpolated for elevations between those simulated by RegCM. Additional fluvial erosion parameters are selected at random from a range of discrete values (Table 1) and river profile erosion is simulated for $16 \mathrm{Myr}$. (d) $\chi^{2}$ misfit. The final river profile is compared with the modern river profile using a $\chi^{2}$ misfit (equation (7)). Input parameters for all simulations that fit the modern river profile with a $\chi^{2} \leq 10$ are stored, and the experiment is repeated with new parameters. 
Table 1. Range of Parameter Values in Monte Carlo Search

\begin{tabular}{|c|c|c|c|}
\hline Parameter & Symbol & Range of Values & Units \\
\hline Erosivity constant & $k_{b}$ & $\begin{array}{l}\text { Erosion Law } \\
5 \times 10^{-34} ; 7.5 \times 10^{-34} ; 1 \times 10^{-33} ; 2.5 \times 10^{-33} ; 5 \times 10^{-33} \\
7.5 \times 10^{-33} ; 1 \times 10^{-32} ; 2.5 \times 10^{-32} ; 5 \times 10^{-32} ; 7.5 \times 10^{-32} \\
\quad 1 \times 10^{-31} ; 5 \times 10^{-31} ; 1 \times 10^{-30}\end{array}$ & $\mathrm{~m}^{5 / 2} \mathrm{yr}^{2} \mathrm{~kg}^{-3 / 2}$ \\
\hline Shear stress exponent & $a$ & $3 / 2$ & dimensionless \\
\hline Grain size & $D$ & $\begin{array}{l}0 ; 0.02 ; 0.05 ; 0.1 ; 0.2 ; 0.3 ; 0.5 ; 1.0 \\
\text { Channel Properties }\end{array}$ & $\mathrm{m}$ \\
\hline Channel width coefficient & $k_{w}$ & 0.001 & $\mathrm{yr}^{b w} \mathrm{~m}^{(3 b w-1)}$ \\
\hline Channel width exponent & $b_{w}$ & $0.40 ; 0.45 ; 0.50 ; 0.55$ & dimensionless \\
\hline Drainage area exponent & $h$ & 1.5 & dimensionless \\
\hline Drainage area coefficient & $k_{a}$ & 130 & \\
\hline $\begin{array}{l}\text { Initial plateau elevation } \\
\text { Uplift stage } 1\end{array}$ & $E_{i}$ & $\begin{array}{l}\text { Tectonics } \\
\qquad 1000-3000 ; 500 \mathrm{~m} \text { interval }\end{array}$ & $\mathrm{m}$ \\
\hline Fraction of total amount & $U_{a}$ & $0-0.9 ; 0.1$ interval & dimensionless \\
\hline Fraction of total time & $U_{t}$ & $\begin{array}{l}0.1-0.9 ; 0.1 \text { interval } \\
\text { Three-Stage Uplift Only }\end{array}$ & dimensionless \\
\hline Fraction of total amount & $U_{a 1} ; U_{a 2}$ & $0-0.8 ; 0.2$ interval & dimensionless \\
\hline Fraction of total time & $U_{t 1} ; U_{t 2}$ & $0-0.9 ; 0.1$ interval & dimensionless \\
\hline
\end{tabular}

1996] indicates the relatively large proportion of the catchment area that lies in the upper reaches, making this catchment particularly sensitive to climatic change in the headwater region. The distribution of precipitation within the catchment, and therefore along-stream discharge volume, is taken from climate simulation results as described in section 3.2. Channel width at node $i$ is related to stream discharge according to

$$
w_{i}=k_{w} Q_{i}^{b_{w}}
$$

where $k_{w}\left(\mathrm{yr}^{b w} \mathrm{~m}^{(3 b w-1)}\right)$ is a dimensional coefficient and $b_{w}$ is a dimensionless positive constant. Empirically determined values of $b_{w}$ vary from $\sim 0.4$ to 0.6 [Leopold and Maddock, 1953; Montgomery and Gran, 2001; Yanites and Tucker, 2010]. In this study, we hold $k_{w}$ constant at $0.001 \mathrm{yr}^{b w} \mathrm{~m}^{(3 b w-1)}$ in all simulations because variation in this parameter is countered by variation of $k_{b}$ and inclusion of $k_{w}$ as a free parameter does not increase the range of plausible uplift histories. However, $b_{w}$ is a free parameter in the Monte Carlo search (Table 1). Values that are both consistent with empirical observations and that give reasonable channel widths were selected to limit the range of search parameters.

[14] The final river incision parameter that is a free parameter in the Monte Carlo search determines the critical shear stress $\left(\tau_{c}\right.$, equations (1a) and (1b)). We assume that the critical shear stress is related to the shear stress required to lift sediment from the bed and expose bedrock [Howard et al., 1994; Lave and Avouac, 2001; Sklar and Dietrich, 2004]. It is evaluated according to

$$
\tau_{c}=\tau_{c}^{*} \Delta \rho g D
$$

where $\tau_{c}^{*}$ is a dimensionless critical shear stress (Shields stress), $\Delta \rho\left(\mathrm{kg} \mathrm{m}^{-3}\right)$ is the density difference between the

Table 2. Constants Used in 1-D River Profile Model

\begin{tabular}{lccc}
\hline \multicolumn{1}{c}{ Variable } & Symbol & Value & Units \\
\hline Darcy-Weisbach friction factor & $C_{f}$ & 0.03 & dimensionless \\
Shields stress & $\tau_{c}$ & 0.045 & dimensionless \\
Density contrast & $\Delta \rho$ & 1650 & $\mathrm{~kg} \mathrm{~m}^{-3}$ \\
Gravitational acceleration & $\mathrm{g}$ & 9.81 & $\mathrm{~m} \mathrm{~s}^{-2}$ \\
Density of water & $\rho_{w}$ & 1000 & $\mathrm{~kg} \mathrm{~m}^{-3}$ \\
\hline
\end{tabular}

fluid and the sediment, $g\left(\mathrm{~m} \mathrm{yr}^{-2}\right)$ is gravitational acceleration, and $D(\mathrm{~m})$ is the median grain size. In the model, critical shear stress values are determined from a range of grain sizes $(D)$ between 0.02 and $1 \mathrm{~m}$ (Table 1 ), which is equivalent to critical shear stresses of $15-730 \mathrm{~Pa}$ when combined with appropriate values of $\tau_{c}^{*}, \Delta \rho$, and $g$ (Table 2). An option of a critical shear stress of zero, and consequently no erosion threshold, is also included in the Monte Carlo search experiments (Table 1).

[15] The evolution of the river profile through time is evaluated by solving equations (1a)-(5) using an explicit, finite difference, forward modeling approach. Equation (1a) is approximated [Tucker, 2004] by

$$
\frac{\mathrm{d} h}{\mathrm{~d} t}=U-\left(k_{b} \tau_{b}^{a}-k_{b} \tau_{c}^{a}\right) \tau_{b}>\tau_{c}
$$

At each time step, the slope values, discharge, and channel width are used to calculate the local shear stress for each node (equation (2)). Node spacing is $500 \mathrm{~m}$ and the model time step is 1000 years. Topography is then updated based on equations (6) and (1b), except for the final node, which is held fixed at sea level. The evolution of the profile and the total amount of incision are tracked throughout the simulation.

\subsection{Initial and Boundary Conditions for the Ocoña Catchment}

[16] Initial and boundary conditions for the Ocoña catchment are defined as follows. The modern elevation of the $16 \mathrm{Ma}$ paleosurface was extracted from a $30 \mathrm{~m}$ ASTER DEM [METI and NASA, 2001] and regional geologic maps [Instituto Geológico Minero y Metalúrgico, 2004] by spline fitting the modern elevation of the Huaylillas ignimbrite base following the method of Schildgen et al. [2007] (see the auxiliary material for details). Assuming negligible hillslope erosion, rock uplift has raised the original paleosurface from an initial, unknown elevation to its modern elevation over the last $16 \mathrm{Myr}$. The geometry of the paleosurface at the onset of the simulation is prescribed as a flat plateau and ramp to zero elevation at the coast (Figure 3a). A rampand-flat geometry was chosen for the initial topography because it defines an uplift rate that is constant on the 
plateau, suggests some outward growth of the plateau, and decreases toward the coast. This pattern is consistent with the conclusion of Schildgen et al. [2009b] who describe the uplift pattern as a combination of monocline development and block uplift. For simplicity, our initial simulations combine these two deformation styles throughout the simulation. We explore scenarios in which monocline uplift switches to block uplift during the late Miocene in section 5.1. Alternative geometries for the initial shape of the paleosurface were explored including a river profile that has a concavity similar to the modern river. However, these geometries require an uplift rate that has a maximum at $\sim 200 \mathrm{~km}$ from the headwaters that is not compatible with regional tectonic development. The initial elevation of the plateau is treated as a free parameter, $E_{i}$, in the Monte Carlo search (Table 1). Plateau elevations of less than $1 \mathrm{~km}$ at $16 \mathrm{Ma}$ are unlikely because significant material had already been shed from the mountain front at this time [Roperch et al., 2006], indicating the prior establishment of significant topography. Conversely, plateau elevations $>3 \mathrm{~km}$ at $16 \mathrm{Ma}$ are inconsistent with geologic evidence for at least $1.5 \mathrm{~km}$ of surface uplift since deposition of regional ignimbrites 16-14 Ma. Simulated initial plateau elevations considered are therefore limited to range between 1 and $3 \mathrm{~km}$ (Figure $3 \mathrm{a}$ and Table 1), with simulations initiated at discrete $500 \mathrm{~m}$ intervals.

[17] In our initial suite of simulations, rock uplift rates are defined to raise the initial surface up to the modern paleosurface elevation in two stages of different rates (Figure 3b). In the model, the rock uplift rate is determined by two random numbers that describe the first uplift stage in terms of the amount of uplift $\left(U_{a}\right)$ that occurs in, and the duration $\left(U_{t}\right)$ of, the first uplift stage (Table 1). The spatial distribution of uplift rates is dependent on the shape of the prescribed initial topography and the magnitude of uplift rates depends on the initial plateau elevation (Figure $3 b$ ). Rock uplift rates and surface uplift are considered to be equivalent because background erosion rates and flexural isostatic response are likely to be small compared to uplift amounts [Lamb, 2011; Simpson, 2004]. We explore more complex uplift histories, including 3 -stage uplift and a component of block uplift, in section 5.1.

[18] The discharge term $(Q / W$, equation (3)) is commonly calculated based on the assumption that precipitation rates are uniform throughout the catchment and that each unit area therefore contributes the same volume to the total discharge. For this study, we account for spatial and long-term variability in precipitation rates by using results from the regional climate model RegCM. Ehlers and Poulsen [2009] and Insel et al. [2010] performed several climate model simulations in which the Andean topography was modified for lower plateau elevations. South American climate was simulated at five different plateau elevations representing modern, $75 \%, 50 \%, 25 \%$, and low $(250 \mathrm{~m})$ Andean elevations. For this study, a northsouth transect of mean annual precipitation rates was extracted across the Ocoña catchment from each of these simulations (Figure 3c). At each point on the climate data transect, mean annual precipitation rates were averaged across three longitudinal grid cells spanning the width of the catchment. RegCM is known to overestimate precipitation rates in this region, so absolute values were scaled to give precipitation rates of $\sim 3.5 \mathrm{~mm} \mathrm{~d}^{-1}\left(\sim 1.3 \mathrm{~m} \mathrm{yr}^{-1}\right)$ in the headwaters (Figure $3 \mathrm{c}$ ) while maintaining the spatial gradient that compares well with observations (Figure 2). In the river incision model, precipitation rates at each time step are interpolated to the appropriate elevation. Climate inputs are not a free parameter in the Monte Carlo search. The Monte Carlo search therefore includes seven free parameters (Table 1) that account for uncertainties in river incision parameterization $\left(k_{b}, b_{w}\right.$, and $\left.D\right)$, initial conditions at $16 \mathrm{Ma}\left(E_{i}\right)$, and surface uplift history $\left(U_{a}\right.$ and $\left.U_{t}\right)$.

\subsection{Model Evaluation Criteria}

[19] For each simulation in the Monte Carlo search, model output is evaluated based on a comparison with the modern river profile and the ability to replicate the timing of incision onset and completion (Figure 3d). The success of the model in simulating the observed river profile is measured using the reduced $\chi^{2}$ misfit function:

$$
\chi^{2}=\frac{1}{n-v-1} \sum_{i}^{n}\left(\frac{\operatorname{sim}_{i}-\mathrm{obs}_{i}}{\text { tolerance }}\right)^{2}
$$

where $n$ is the number of nodes on the river profile (601 nodes, $500 \mathrm{~m}$ spacing), $v$ is the number of free variables, $\operatorname{sim}_{i}$ is the simulated river elevation at node $i$, and $\mathrm{obs}_{i}$ is the elevation of the smoothed, observed river profile at node $i$. The tolerance is $150 \mathrm{~m}$, given by the estimated error on the filled and smoothed river profile extracted from a $30 \mathrm{~m}$ ASTER DEM [METI and NASA, 2001]. In this study, the western, Maran, branch of the river (Figure 1) is simulated because it is more deeply incised. Furthermore, the upper Cotahuasi (eastern) branch was filled by volcanics $\sim 2 \mathrm{Ma}$ which complicates model evaluation based on the modern river profile [Thouret et al., 2007]. To ensure that previously glaciated regions were not included in the analysis, the observed profile was truncated at $\sim 50 \mathrm{~km}$ from the headwaters (Figure 3 ). The $\chi^{2}$ misfit is a measure of how well the model reproduces the shape and elevation of the modern river profile. The $\chi^{2}$ misfit also measures the total amount of incision, because the total amount of incision is the difference between the elevation of the modern river profile and the modern elevation of the 16 Ma paleosurface, which is fixed for all simulations. Only simulations that yield a $\chi^{2}$ misfit $\leq 2$ (Figure 4) are discussed in the results (section 4).

[20] Acceptable river simulations must also obey two constraints on the timing of incision: (1) erosion into the paleosurface must be less than $600 \mathrm{~m}$ at $12 \mathrm{Ma}$ along the full length of the profile, and (2) at least $90 \%$ of the total incision must have occurred by $2 \mathrm{Ma}$ between 80 and $125 \mathrm{~km}$ from the river outlet. Hereafter, these two constraints are referred to as the "incision onset constraint" and the "incision completion constraint," respectively. Incision onset timing is constrained by modeling of thermochronometry data [Schildgen et al., 2009b] and dated channel fill deposits [Thouret et al., 2007]. Timing of incision completion is constrained by dated volcanic deposits close to, or at, the present-day valley floor (Figure 1) [Schildgen et al., 2007; Schildgen et al., 2009b; Thouret et al., 2007]. The model constraints were chosen as a combination of multiple available constraints with the goal of identifying simulations that display both an increase in incision rate during the first few million years of simulation and a slowing to near-completion by the end of the simulation. Due to the simplicity of the model, stricter constraints that more faithfully represent some of the geological observations, for example, less than $300 \mathrm{~m}$ incision by $8 \mathrm{Ma}$ and $100 \%$ complete incision by $2 \mathrm{Ma}$, result in the rejection of all simulated scenarios. In the following 


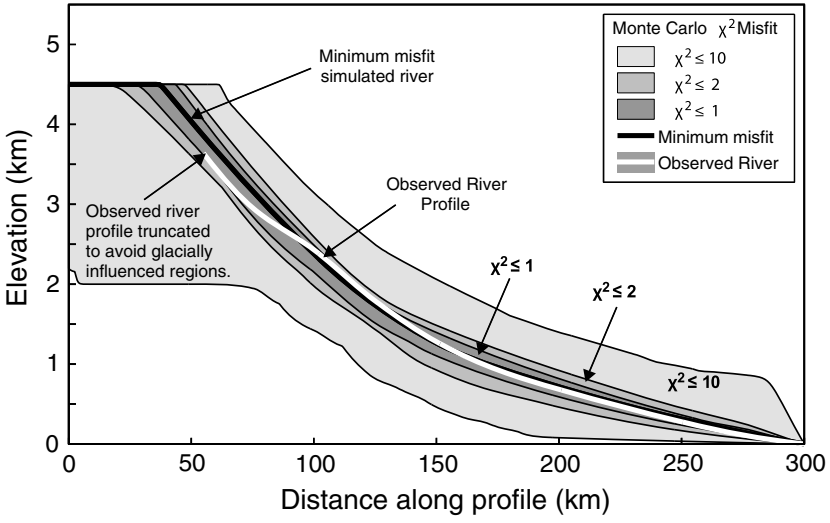

Figure 4. Range of simulated river profiles that match the modern river profile (white) within a specified $\chi^{2}$ limit. The final river profile with the lowest $\chi^{2}$ misfit found by the Monte Carlo search is shown in black. The modern river profile is truncated at $\sim 50 \mathrm{~km}$ to remove the region influenced by glacial erosion and the $\chi^{2}$ misfit is calculated only for the portion of river shown.

section, we therefore demonstrate the different effects of climate and tectonics factors on profile evolution under relatively simple tectonic and incision conditions and discuss more complicated uplift models in sections 5.1.1 and 5.1.2.

\subsection{Model Caveats}

[21] Geological factors that are not explicitly accounted for in the model include drainage re-organization, lithological variations, volcanic valley infill, mass wasting, and glaciation. The model assumes that the river is governed by detachment-limited erosion that includes a threshold; variations in sediment flux are not accounted for. The shearstress incision law approach presented here is an approximation of a more complete treatment of incision thresholds under stochastic discharge conditions [Lague et al., 2005; Snyder et al., 2003; Tucker, 2004]. Short-term precipitation variability is not sufficiently well resolved by existing paleoclimate model simulations to enable the use of a stochastic discharge model in this study. A more rigorous approach that includes short-term precipitation variability is a future research goal. It is therefore assumed that $\mathrm{RegCM}$ precipitation rates are representative of the long-term discharge and that all precipitation becomes surface runoff. Finally, surface uplift is prescribed to occur in two stages, which do not permit more complex uplift histories. In order to validate our results, we examine and quantify (see sections 5.2 and 5.3) the impact of these factors on the results using additional Monte Carlo searches with slightly modified model formulation.

\section{Results}

[22] Monte Carlo searches were successful in finding a range of geologic and geomorphic parameters that fit the observational constraints defined in section 3.3. Experiment results are presented in the following way. First, the sensitivity of the model to climate and tectonics is demonstrated with example simulations using parameter values chosen from the suite of successful simulations. Second, results of the Monte Carlo search are presented in terms of plausible plateau uplift histories. Finally, the influence of erosion parameters on the model is examined. The fit of the Monte Carlo model to the data is presented in the following two ways: (1) A "good-fit" simulation is defined here as one that obeys the geologic timing constraints and fits the modern river profile with a $\chi^{2}$ misfit $\leq 1$ (equation (7)). This criterion was chosen because it implies the model is fitting the observed modern river profile within one standard deviation of uncertainty in elevation. (2) An "acceptable" simulation is defined as one that obeys the timing constraints and river profile elevation with a $\chi^{2}$ misfit $\leq 2$. This criterion means the model fits the modern river profile elevation at the two standard deviation level. Simulation results with larger $\chi^{2}$ misfit values (e.g., $\chi^{2}$ misfit $\leq 10$; Figure 4) are shown only for reference to illustrate model sensitivity to poor combinations of parameters.

\subsection{Demonstration of Model Behavior}

\subsubsection{Baseline Simulation}

[23] Results are shown for three individual simulations to illustrate the model setup and behavior with respect to different parameter choices. The first of these is the "baseline simulation" (Figure 5), which is an example of a single simulation (i.e., without a Monte Carlo search) that yields a good fit to observations. The baseline simulation was initiated with a plateau elevation of $2 \mathrm{~km}$ at $16 \mathrm{Ma}$. Surface uplift rates of $\sim 0.24 \mathrm{~mm} \mathrm{yr}^{-1}$ on the plateau were applied between 16 and $9.6 \mathrm{Ma}$ (Figure 5a). At 9.6 Ma, uplift rates on the plateau were reduced to $\sim 0.11 \mathrm{~mm} \mathrm{yr}^{-1}$ and remained at this rate until the end of the simulation (present day). Precipitation rates change with increasing plateau elevation according to RegCM climate model simulations (Figure 3c). The river profile was recorded every $4 \mathrm{Ma}$ throughout the simulation (Figure 5b) and tracks the response of the river to both surface uplift and changing precipitation rates. The initial river profile at $16 \mathrm{Ma}$ (Figure $5 \mathrm{~b}$ ) is a flat ramp to the coast. Incision is initially strongest at the coast $(300 \mathrm{~km}$; Figure $5 \mathrm{~b})$ and propagates inland through time with active incision dissecting the plateau margin after $\sim 12 \mathrm{Ma}$. At the end of the simulation, the river is still actively incising. The most distal $50 \mathrm{~km}$ of the river profile attain steady state by $8 \mathrm{Ma}$.

[24] The timing and spatial distribution of incision are also recorded throughout the simulation. The total amount of incision is recorded in $2 \mathrm{Ma}$ intervals (Figure 5c). Maximum total amounts of incision are greater than $2.5 \mathrm{~km}$ and occur in the middle reaches of the river $(\sim 150 \mathrm{~km}$ along the profile; Figure $5 \mathrm{c}$ ). In the baseline simulation, the amount of incision between 16 and $14 \mathrm{Ma}$ is low $(<200 \mathrm{~m})$. Through time, incision rates increase and the locus of maximum incision rate (denoted by the distance between two adjacent lines) propagates upstream. By $2 \mathrm{Ma}$, maximum incision rates are located at $\sim 90 \mathrm{~km}$ along the profile and the most distal $\sim 100 \mathrm{~km}$ are at, or near, topographic steady state (Figures $5 \mathrm{~b}$ and $5 \mathrm{c}$ ).

[25] Figure 5c also demonstrates how the incision-timing constraints are used to evaluate the model. If the total erosion at $12 \mathrm{Ma}$ lies outside of the gray shaded area $(600 \mathrm{~m}$ total incision), the simulation violates the incision onset constraint. Similarly, the total erosion since $2 \mathrm{Ma}$ must lie within the red-shaded box (10\% of the total erosion), to obey the incision completion constraint. In this baseline simulation, the final river profile fits the modern observed river with a $\chi^{2}$ misfit of 0.39 (Figure $5 \mathrm{~d}$ ). In this example, all three 
(a)

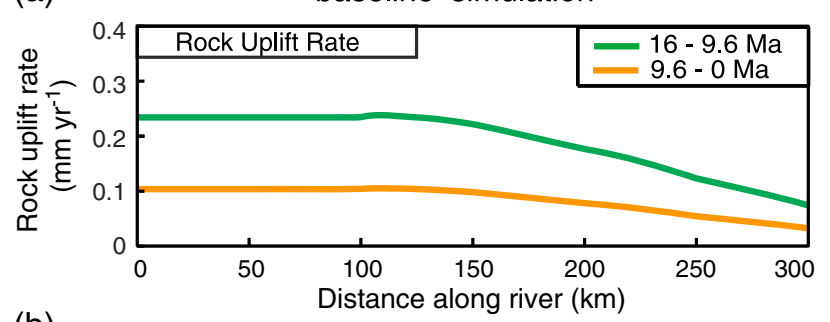

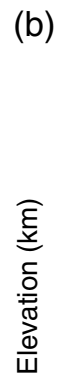

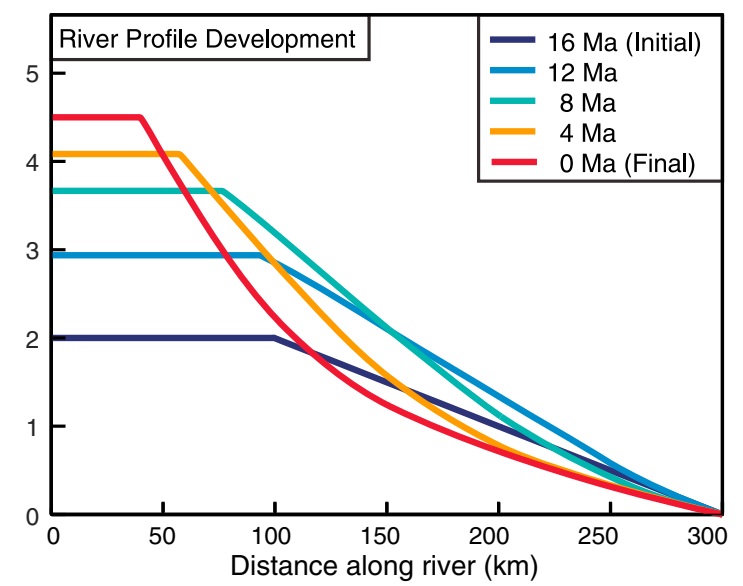

(c)

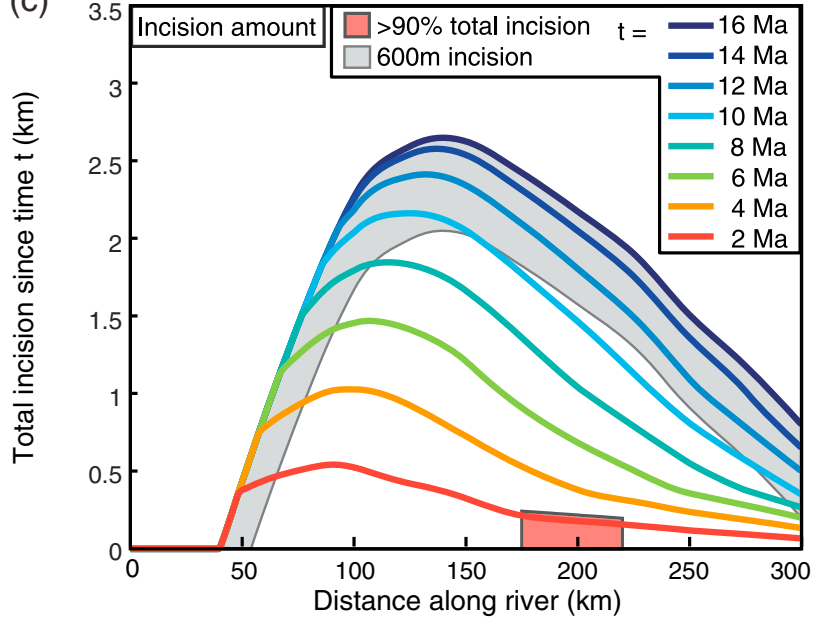

(d)

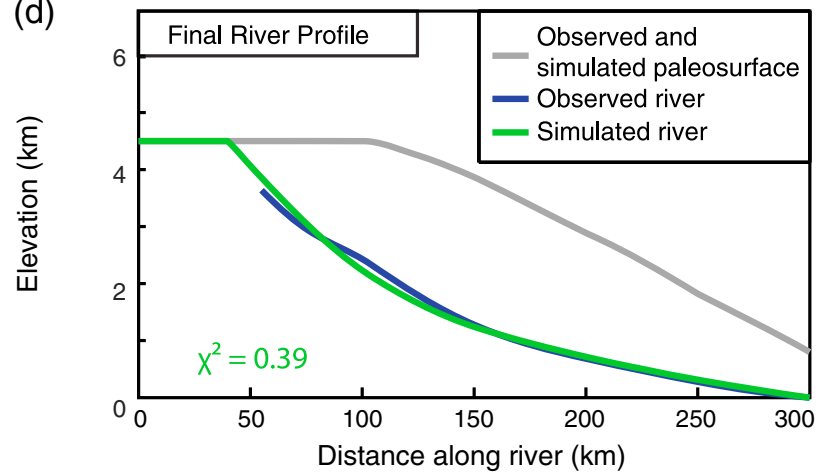

evaluation criteria are met and the model is considered to represent a good fit to the observations. In a Monte Carlo search, the input parameters would be stored and included in the range of good fit results. If any of these three criteria were not met, then the experiment is discarded. For a given set of erosion parameters, the simulations are sensitive to the tectonic and climatic conditions. We demonstrate this sensitivity with two additional individual experiments. As with the previous simulation (Figure 5), these experiments are individual simulations and a Monte Carlo search is not used.

\subsubsection{Tectonic Sensitivity Experiment}

[26] In the first of these, the "tectonic sensitivity experiment," uplift rates are held steady at $\sim 1.6 \mathrm{~mm} \mathrm{yr}^{-1}$ throughout the simulation (Figure 6). Uplift rates during the first 6.4 Myr of simulation are therefore lower than the baseline simulation, and uplift rates since $9.6 \mathrm{Ma}$ are higher than the baseline simulation (Figure 6a). Due to the lower initial uplift rates, the river gradient from the plateau margin to the coast is lower than the baseline simulation (Figure 6b). Additionally, because plateau elevations are lower during the simulation, and precipitation rates increase with increasing elevation (Figure 3c), the discharge is also lower than in the baseline simulation. Consequently, initial incision rates are lower and incision propagates upstream more slowly (Figure 6b).

[27] Slower incision rates throughout the simulation result in less total erosion than the baseline experiment (Figure 6c). Total incision is less than $90 \%$ between 80 and $125 \mathrm{~km}$ from the outlet by $2 \mathrm{Ma}$ and the incision completion constraint is therefore broken. Furthermore, the total erosion throughout the simulation is too low (Figure 6d) and the final river profile has a $\chi^{2}$ misfit of 2.65 . A steady uplift from $2 \mathrm{~km}$ at $16 \mathrm{Ma}$ is therefore not compatible with the incision constraints under the specified erosion parameters because incision rates are initially too low due to the lower elevation, but the increase in uplift rate results in incision rates that are too high during the last $4 \mathrm{Ma}$ of simulation.

\subsubsection{Climate Sensitivity Experiment}

[28] In the final individual experiment, we demonstrate the importance of the long-term temporal variation of precipitation by holding precipitation rates constant through time. Precipitation rates are therefore not linked to plateau elevation, as is the case in the previous simulations (Figures 5 and 6). The previous experiment (Figure 6) showed how a combination of topographic and precipitation conditions controls the timing of the onset of rapid incision. By holding precipitation rates constant, we demonstrate the importance

Figure 5. Rock uplift rates and model output for an example "baseline" simulation. (a) Rock uplift rates applied between 16 and $9.6 \mathrm{Ma}$ (green), and 9.6 and $0 \mathrm{Ma}$ (orange). (b) River profile development at $4 \mathrm{Myr}$ intervals during the simulation. (c) Total incision since time $t$. Differences between consecutive time lines indicate the amount of erosion that occurred in that time interval. Incision onset constraint: maximum of $600 \mathrm{~m}$ incision before $12 \mathrm{Ma}$ (gray shading). Incision completion constraint: at least $90 \%$ of incision must occur by $2 \mathrm{Ma}$ (red shading). (d) Simulated final river profile (green), observed modern profile (blue), and simulated and observed modern elevation of $16 \mathrm{Ma}$ paleosurface (gray). The $\chi^{2}$ misfit for this simulation is 0.87 . 
of elevation-dependent precipitation. For the simulation shown in Figure 7, all model parameters are identical to those in the baseline simulation (Figure 5) except for precipitation rates, which are taken from the $100 \%$ Andean elevation case (Figure 3c). Modern precipitation rates enable rapid incision at low $(<3 \mathrm{~km})$ plateau elevations. The lower reaches of the river quickly approach topographic steady state (200-300 km along profile; Figure 7b). Incision amounts between 16 and $12 \mathrm{Ma}$ are high enough to break the incision onset constraint between 210 and $230 \mathrm{~km}$ along the river profile (Figure 7c). A constant precipitation rate also results in greater total incision amounts (Figure 7d) giving a final river profile $\chi^{2}$ misfit of 2.06 , lower than with the steady uplift rate, but higher than the baseline simulation (Figure 7d).

[29] Together, these three experiments demonstrate how different tectonic and climatic conditions can alter the river profile evolution for a specific set of erosion parameters. However, simulations with a different uplift rate or initial elevation may be compatible with geological constraints under a different set of erosion parameters $\left(b_{w}, D\right.$, and $\left.k_{b}\right)$. Monte Carlo searches over a wide range of parameter values are therefore needed to establish the full range of plausible uplift histories. The following sections present Monte Carlo search results.

\subsection{Monte Carlo Results for Northern Altiplano Surface Uplift Histories}

[30] A Monte Carlo search, performed as described in section 3 (see also Figure 3), with $1.64 \times 10^{5}$ simulations identifies a wide range of uplift histories that produce acceptable or good fit results. Figure 8 a shows the range of plateau uplift histories that are compatible with geological constraints. Ranges of plateau uplift histories are shown for cumulatively applied constraints, to demonstrate how each of the good fit criteria (incision onset constraint, incision completion constraint, and river $\chi^{2}$ misfit) determines the final set of results. Each shaded region encompasses several individual uplift histories that fit the specified constraints (Figure 8b). Not all past elevation paths within the shaded region can necessarily produce a good fit result, rather all good fit results lie within the shaded region. Different regions indicate how each individual constraint determines the acceptable uplift history range. In these, and all following figures, "plateau elevation" refers to the elevation of the undissected plateau (e.g., Figure 7b).

[31] Monte Carlo searches reproduce the modern river profile with a $\chi^{2}<2$ under a wide range of uplift histories, and the $\chi^{2}$ misfit alone does not define a meaningful uplift history range (Figure 8a, region 1). This range includes uplift histories with initial elevations at $16 \mathrm{Ma}$ between 1.5 and $3 \mathrm{~km}$, those with close to modern elevations at $14 \mathrm{Ma}$, and those in which elevations remain below $2 \mathrm{~km}$ until $2 \mathrm{Ma}$. The more extreme of these uplift scenarios is geologically unrealistic. Applying incision-timing constraints greatly reduces the range of acceptable uplift histories. Application of the incision onset constraint results in the rejection of uplift histories in which high $(>3.5 \mathrm{~km})$ plateau elevations are attained prior to $13 \mathrm{Ma}$ (Figure 8a, region 2). Application of the incision completion constraint reduces the parameter space by rejecting scenarios in which low elevations persist throughout the simulation (Figure 8a, region 3). The range of uplift histories is reduced still further when results are restricted to those that fit both geological constraints and have a river $\chi^{2}$ misfit $<1$ (Figure 8a, region 4). Of the $1.64 \times 10^{5}$ scenarios tested, 114 produced an acceptable fit to the model constraints (Figure 8a, region 3 ) and 52 produced a good fit to the model constraints (Figures $8 \mathrm{a}$ and $8 \mathrm{~b}$, region 4 ).

[32] In combination, the constraints require that plateau elevations were $1.5-3 \mathrm{~km}$ at $16 \mathrm{Ma}$, reached a minimum of $\sim 3 \mathrm{~km}$ by $10 \mathrm{Ma}$, and were $\sim 3.5 \mathrm{~km}$ by $5 \mathrm{Ma}$. Plateau elevations close to the modern may have been attained as early as $6 \mathrm{Ma}$ and as late as $<1 \mathrm{Ma}$. Individual uplift paths (Figure 8b) indicate that with one exception, most good fit simulations have an uplift history that slows over time. The switch to a lower uplift rate occurs anywhere between 14 and $5 \mathrm{Ma}$. Only uplift rates that were close to, or less than, $\sim 0.1 \mathrm{~mm} \mathrm{yr}^{-1}$ over the last $6 \mathrm{Ma}$ are compatible with the incision completion constraint.

\subsection{River Incision Parameters}

[33] The Monte Carlo search identifies not only the range of uplift histories but also the range of river erosion parameters that are capable of producing good fit results. The number of simulations that produced acceptable or good fit results with each discrete value of parameters $k_{b}, D$, and $b_{w}$, and the initial elevation, $E_{i}$, is shown in Figure 9. Simple, individual simulations (not shown) demonstrate that the sensitivity of profile evolution to an individual erosion parameter is significant. However, many parameter values included in the search yield an acceptable fit when combined with an appropriate combination of other parameters. Search results demonstrate that the erosivity constant, $k_{b}$, is limited to between $1.25 \times 10^{-33}$ and $50 \times 10^{-33} \mathrm{~m}^{5 / 2} \mathrm{yr}^{2} \mathrm{~kg}^{-3 / 2}$ (Figure 9a). The largest number of good fit results were found for $k_{b}=2.5 \times 10^{-33} \mathrm{~m}^{5 / 2} \mathrm{yr}^{2} \mathrm{~kg}^{-3 / 2}$.

[34] The frequency plots do not indicate a strong preference for particular values of the other model parameters. The range of grain sizes that resulted in acceptable fit simulations is limited to those with a median grain size of less than $10 \mathrm{~cm}(D$; Figure 9b), corresponding to a critical shear stress of $73 \mathrm{~Pa}$. No simulations with zero-erosion threshold were successful at the $\chi^{2} \leq 1$ level, which indicates the importance of including an erosion threshold in the model formulation and suggests that threshold processes were important in the evolution of the canyon. Only values of $b_{w}$ between 0.4 and 0.5 produced good fit results (Figures 9c and 9d), and only three simulations with $b_{w}$ equal to 0.55 gave an acceptable fit to the results. There is significant overlap between uplift histories found with different values of $b_{w}$. However, the good fit initial plateau elevation values are sensitive to the choice of $b_{w}$. For example, for $b_{w}=0.5$, the range of initial plateau elevation ranges from 2 to $3 \mathrm{~km}$, whereas for $b_{w}=0.45$, initial plateau elevation ranges from 1.5 to $2.5 \mathrm{~km}$ and good fit uplift rates from $10 \mathrm{Ma}$ to present are higher than for $b_{w}=0.5$. This finding underscores the importance of considering the dynamics of channel width in modeling the evolution of slope in tectonically active landscapes. Similarly, larger median grain sizes, and therefore a higher erosion threshold, require more easily erodible substrate to produce a good fit to the constraints. Figure 8 emphasizes the benefits of using a Monte Carlo search approach to the investigation of river incision development. The three river erosion parameters are under-constrained for the river of interest, and assuming a single value for each 

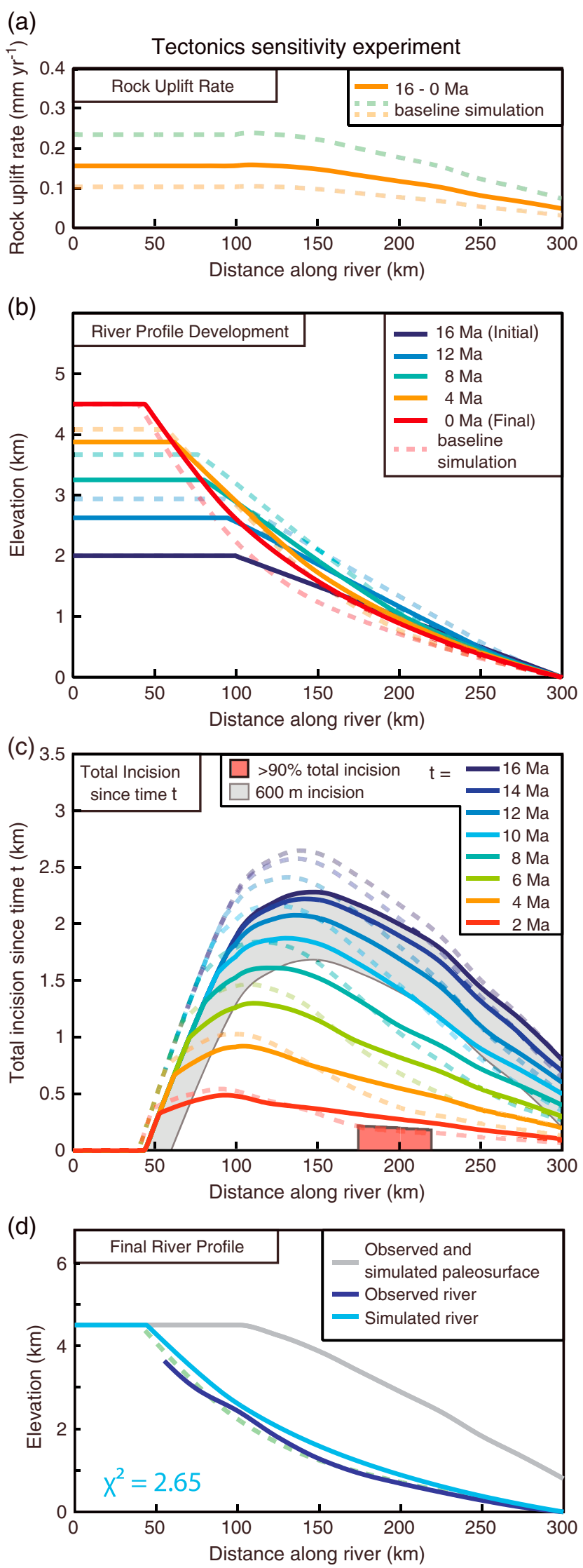

parameter would have resulted in the omission of plausible uplift histories (Figure 8).

\section{Discussion}

\subsection{Surface Uplift of the Northern Altiplano}

[35] This study is motivated by the hypothesis that the influence of climate change on river incision could reconcile observations of high-magnitude river incision with a slow and steady end-member model of surface uplift [Barnes and Ehlers, 2009; Ehlers and Poulsen, 2009]. Our results show that a wide range of northern Altiplano uplift histories are consistent with records of incision on the western flanks. Our results suggest that at $16 \mathrm{Ma}$, the northern Altiplano was between 1 and $3 \mathrm{~km}$ elevation (Figure 8), by $10 \mathrm{Ma}$ elevations had reached $3-3.75 \mathrm{~km}$, and by 5 Ma plateau elevations exceeded $3.5 \mathrm{~km}$. Both the range of good fit uplift histories (Figure 8) and uplift paths from individual simulations indicate that uplift rates slowed through time. That is, most successful search results indicate that uplift rates were slower in the second uplift stage than the first uplift stage. Timing of the transition between the two uplift stages varies considerably between 14 and $5 \mathrm{Ma}$ and is independent of the initial plateau elevation.

[36] Incision-timing constraints play an important role in determining the good fit uplift history range shown in Figure 8. The incision onset constraint determines the upper limit of plateau elevation through time and requires that plateau elevations were below $3.5 \mathrm{~km}$ until $13 \mathrm{Ma}$. In contrast, the incision completion constraint determines the lower limit of plateau elevation development. Volcanic deposits that are close to the modern day river elevation and dated at $\sim 2 \mathrm{Ma}$ were used to define the incision completion constraint (Figure 1b). Simulations that have sufficiently low incision rates during the last $2 \mathrm{Ma}$ to fit this constraint are those in which recent $(<5 \mathrm{Ma})$ plateau uplift rates are low (less than $\sim 0.1 \mathrm{~mm} \mathrm{yr}^{-1}$ ) and the river profile is approaching topographic steady state. The lack of knickpoints is consistent with, though not conclusive evidence for, topographic steady state. Other processes, such as a reduction in precipitation, lithological boundaries, drainage re-organization, or volcanic infill, can limit incision rates and may explain the small incision magnitudes since $2 \mathrm{Ma}$. If these processes are important, modern uplift rates may be higher than those found in the Monte Carlo process. It is unlikely that a lithological

Figure 6. This simulation (tectonics sensitivity experiment) is identical to the baseline experiment (Figure 5) except uplift rates are held steady at $\sim 1.6 \mathrm{~mm} \mathrm{yr}^{-1}$ through the simulation. For comparison, the results of the baseline experiment (Figure 5) are shown as dashed lines and the following comments describe differences between the two experiments. (a) Uplift rates are lower between 16 and 9.6 Ma and higher between 9.6 and $0 \mathrm{Ma}$. (b) The elevation of the river profile remains similar throughout the simulation as the paleosurface is uplifted around the canyon. (c) Incision rates at the end of the simulation are higher, but $90 \%$ incision is not achieved by $2 \mathrm{Ma}$ and the incision completion constraint is broken. (d) The final river is not so deeply incised with a $\chi^{2}$ misfit of 2.65 . This simulation therefore does not yield a good fit to the observations. 
(a)

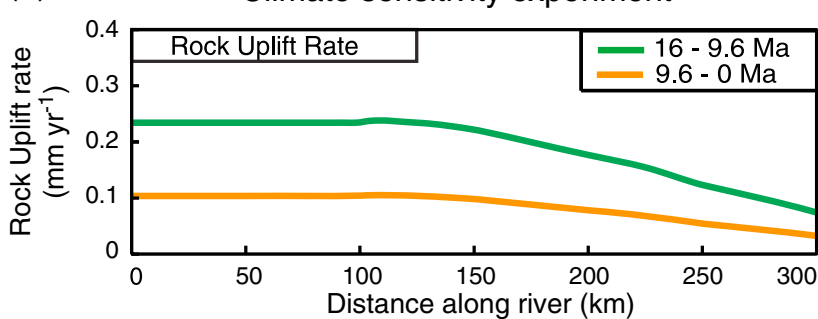

(b)

(c)
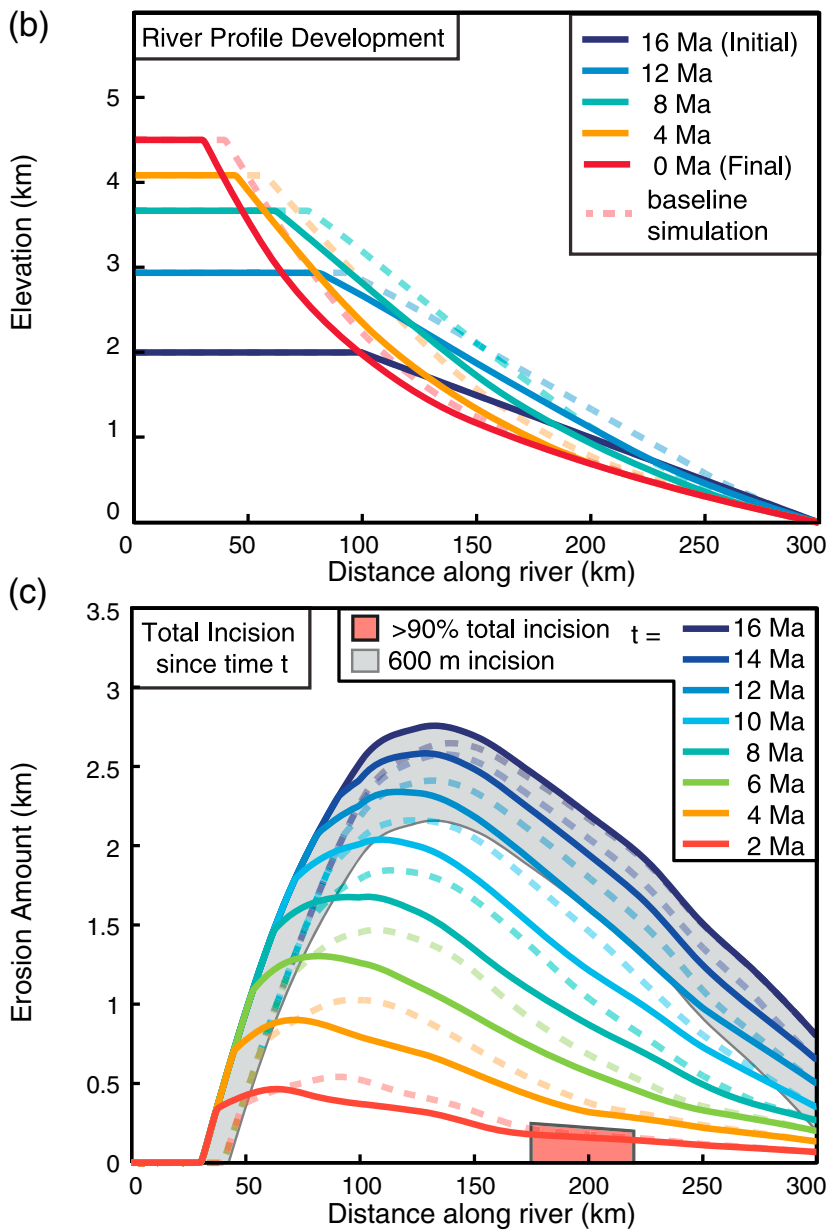

(d)

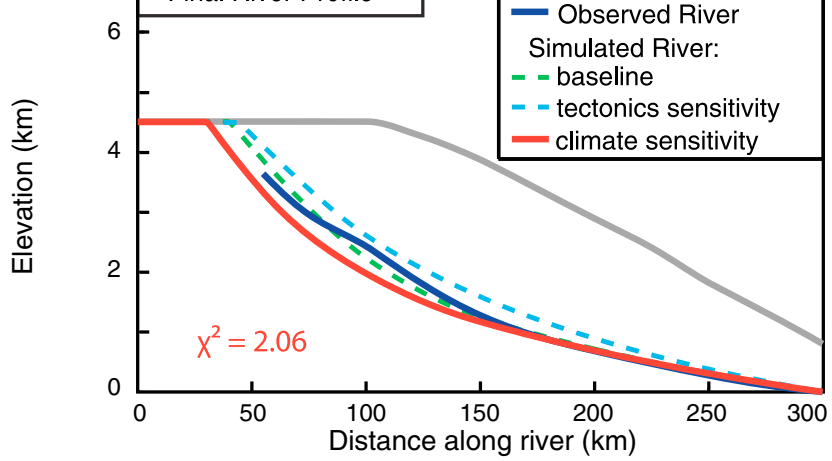

change caused a slowing of incision rates in the last $2-5 \mathrm{Ma}$ because the river has incised through $>1 \mathrm{~km}$ of Paleozoic to Mesozoic intrusive rocks. Volcanic valley fill may have slowed river incision by covering the valley base and by providing an additional source of sediment that would delay bedrock incision until the sediment was flushed out of the system.

\subsubsection{Three-Stage Uplift Scenario}

[37] Stable isotope-based paleo-elevation reconstructions from the southern Altiplano that assume no change in climate from the modern suggest that a phase of rapid elevation increase of up to $\sim 2 \mathrm{~km}$ occurred between 10 and $6 \mathrm{Ma}$ [Hoke and Garzione, 2008; Garzione et al., 2008; Ghosh et al., 2006; Quade et al., 2007]. By prescribing a two-phase uplift history, the model setup presented in Figure 8 does not permit a pulse of rapid uplift during the late Miocene and therefore does not permit a fair comparative evaluation of the slow and steady and punctuated end-member models of surface uplift [Barnes and Ehlers, 2009]. We address this alternative uplift scenario with an additional Monte Carlo search in which uplift is permitted to occur in three stages (Figure 10). In order to reduce the number of possible parameter combinations and to make the search viable, the discretization of parameter space is coarser than in the two-stage uplift search. During each stage, uplift amounts $\left(U_{a 1}\right.$ and $\left.U_{a 2}\right)$ are discretized at $0,0.2,0.4,0.6$, and 0.8 times the total elevation increase (Table 1). To evaluate this, we conducted an additional $1.6 \times 10^{6}$ Monte Carlo simulations, of which 1013 produced an acceptable fit to the model constraints and 352 produced a good fit to the model constraints.

[38] The initial elevation range found by the three-stage uplift search is greater than that found in the two-stage uplift search (1-3 km; Figures 8 and 10). Furthermore, the threestage uplift permits a wider range of elevations throughout the remainder of the simulation duration. For three-stage uplift, good fit results indicate that the plateau surface elevations were between 2.75 and $4 \mathrm{~km}$ at $10 \mathrm{Ma}$ and between 3.0 and $4.25 \mathrm{~km}$ at $5 \mathrm{Ma}$. Good fit results include some that are consistent with the punctuated uplift end-member model. These simulations have uplift rates that are initially low $\left(<0.15 \mathrm{~mm} \mathrm{yr}^{-1}\right)$ followed by a pulse of high uplift rates. However, the timing of the uplift pulse is generally earlier than that found in proxy records. Simulated uplift pulses begin 14-11 Ma and last for 1.5-3 Myr, before decreasing for the final uplift stage. The Monte Carlo search also found good

Figure 7. This simulation (climate sensitivity experiment) is identical to the baseline experiment (Figure 5) except that the precipitation rate is held at rates corresponding to $100 \%$ Andean elevation (see Figure 3c) throughout the simulation. For comparison, the results of the baseline experiment (Figure 5) are shown as dashed lines and the following comments describe differences between the two experiments. (a) Uplift rates for each stage are identical. (b) River incision is more rapid at the onset of the simulation and the lower reaches attain topographic steady state at an earlier time. (c) Total incision by $12 \mathrm{Ma}$ exceeds $600 \mathrm{~m}$, breaking the incision onset constraint. (d) The final river profile has a $\chi^{2}=2.06$. It is more deeply incised than the baseline and tectonics sensitivity experiments. This simulation does not yield a good fit to the constraints. 
(a)

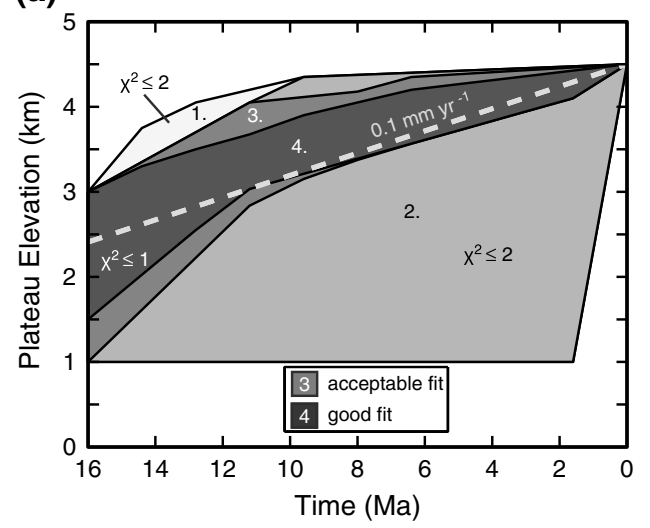

(b)

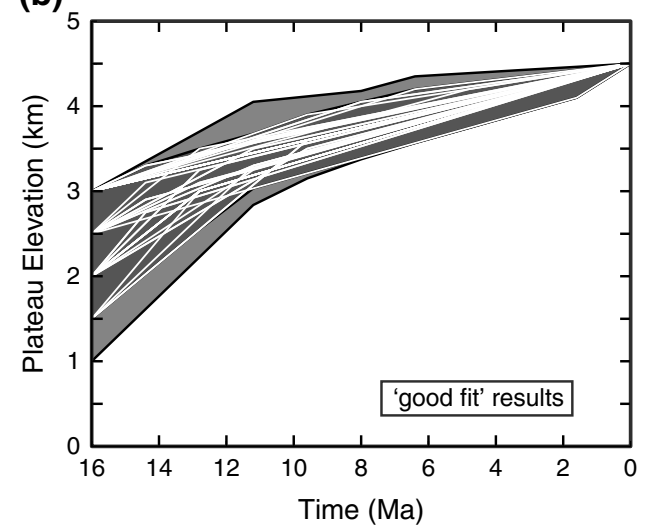

\begin{tabular}{|c|c|c|c|}
\hline region & $\begin{array}{c}\text { Geological c } \\
\text { Incision onset } \\
\text { constraint } \\
\end{array}$ & $\begin{array}{l}\text { nstraints applied: } \\
\text { Incision completion } \\
\text { constraint }\end{array}$ & $x^{2}$ \\
\hline 1. & & & 2 \\
\hline 2. & & & 2 \\
\hline 3. & & $\checkmark$ & 2 \\
\hline 4. & & $\checkmark$ & 1 \\
\hline
\end{tabular}

Figure 8. (a) Past plateau elevations that produce acceptable fits to the following cumulatively applied, geological constraints in a Monte Carlo search: (1) river $\chi^{2}$ misfit less than or equal to 2; (2) incision onset constraint - total incision at $12 \mathrm{Ma}$ must be less than $600 \mathrm{~m}$; (3) incision completion constraint-incision is at least $90 \%$ complete by $2 \mathrm{Ma}$; and (4) simulations that fit both timing constraints with a river $\chi^{2}$ misfit less than or equal to 1 . An uplift rate of $0.1 \mathrm{~mm} \mathrm{yr}^{-1}$ is shown for reference (dashed gray line). "Acceptable" and "good" fit results are shown as regions 3 and 4, respectively. (b) Individual plateau uplift histories (white) that define region 4 of Figure 8a.

fit scenarios in which uplift rates are slowest during the second stage, and those in which uplift rates are close to steady throughout the simulation. The lower bound on acceptable past plateau elevation is lower for three-stage uplift than two-stage throughout the time period of simulation. The upper bound on the plateau elevation range is similar.

[39] Uplift histories constrained by incision of the Ocoña canyon are consistent with either a slow and steady or a punctuated model of surface uplift. In reality, it is likely that the regional uplift history was more complex than any of the scenarios explored in this study, both in space and in time. For example, coastal morphology suggests renewed uplift of $>100 \mathrm{~m}$ during the Quaternary [Regard et al., 2010]. However, existing geological constraints do not require or enable the identification of these complexities. Because the Ocoña canyon is located at the northern margin of the Altiplano, the range of uplift histories presented here are most relevant to the northern Altiplano. However, climate change as a result of Andean uplift may also help to explain incision amounts and timing elsewhere on the Altiplano flanks. Climate-driven incision may have been more substantial on the eastern flanks where the magnitude of precipitation change was greatest.

\subsubsection{Block Uplift Scenario}

[40] Based on combined sedimentology and thermochronology observations, Schildgen et al. [2009a] suggested that uplift of the south Peruvian forearc occurred in two phases with distinct styles. Within $\sim 50 \mathrm{~km}$ of the coast, a regional bajada surface is capped by coarse river gravels that are thought to have graded to sea level at the time of abandonment. Intercalated ashes indicate that the bajada was active until $\sim 5 \mathrm{Ma}$ in the Vitor and Sihuas valleys, to the east of the Ocoña catchment. These valleys also contain large $(\sim 1 \mathrm{~km})$ knickpoints at $40-60 \mathrm{~km}$ from the modern coastline that are likely related to abandonment of the bajada surface [Schildgen et al., 2009a]. Similar gravels are present in the Ocoña catchment, but no major knickpoint is present due to the relatively faster response time of the larger catchment. To account for both incision onset prior to $\sim 8 \mathrm{Ma}$ and active, shallow river channels near the coast at $\sim 5 \mathrm{Ma}$, Schildgen et al. [2009a] propose a change in uplift style $\sim 5 \mathrm{Ma}$. In this scenario, the western cordillera was initially uplifted relative to the piedmont by monoclinal folding during phase one, followed by a second phase of $\sim 1 \mathrm{~km}$ of block uplift extending from the plateau to the coast.

[41] The original Monte Carlo search presented does not include a stage of block uplift, and due to the model formation, incision of the piedmont begins early $(<14 \mathrm{Ma})$ in all simulations. We therefore test the above scenario with a suite of simulations in which the uplift style is prescribed to change from monoclinal to block uplift during the simulation. During phase one (monoclinal uplift), two uplift stages are permitted to raise the paleosurface from the initial elevation to a prescribed height below the modern paleosurface elevation. Phase two (block uplift) is permitted to begin between 9.6 and 3.2 Ma. The uplift amount during phase two is defined as the modern elevation of the paleosurface at the coast $(800 \mathrm{~m})$. All other parameter ranges are the same as in the original Monte Carlo search (Table 1 and Figure 8), and precipitation rates are prescribed to vary with plateau elevation (Figure 3c). Simulations are evaluated in the same way as the previous 

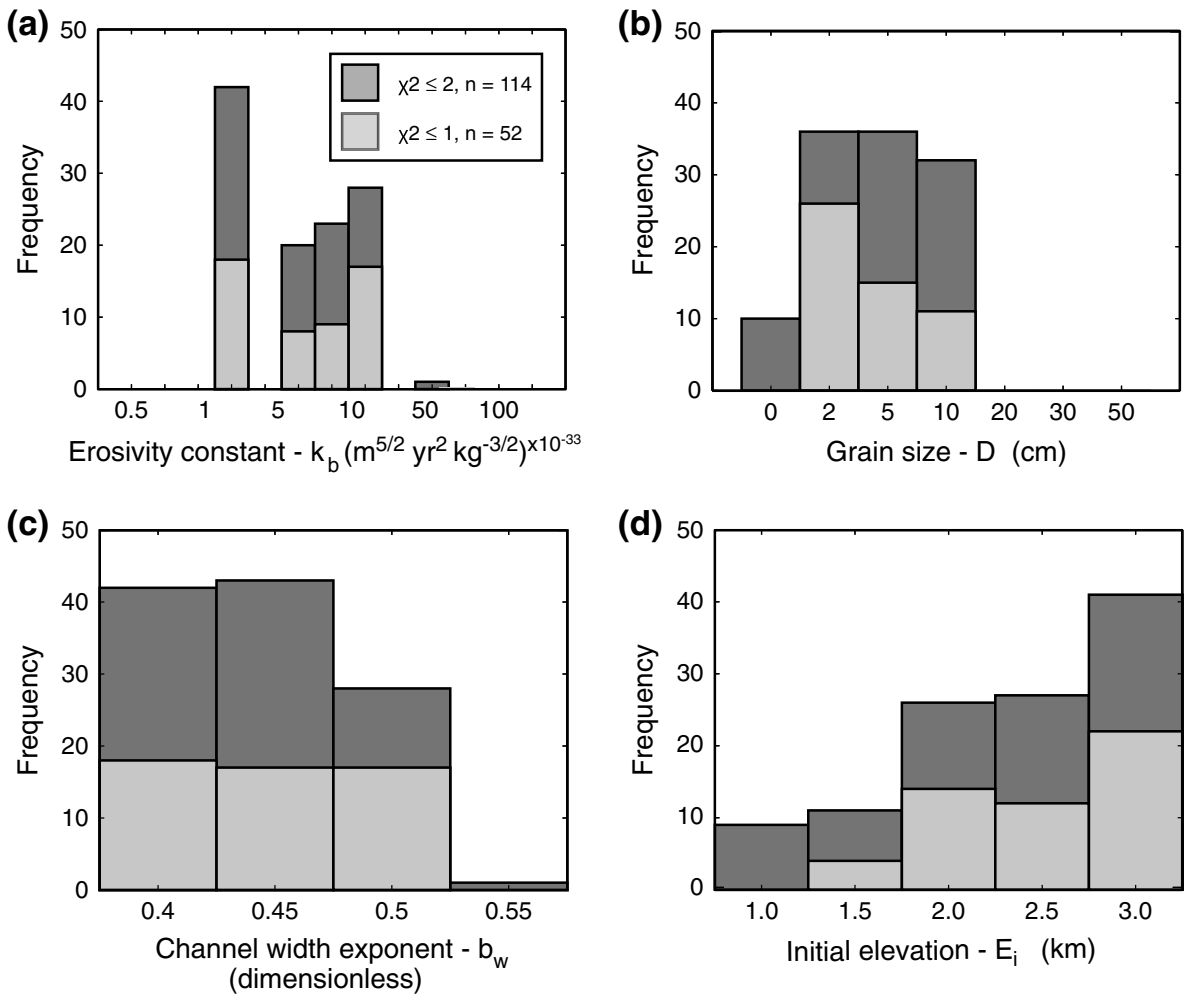

Figure 9. Frequency histograms of the number of simulations that yielded fits to both timing constraints and the modern river profile with a $\chi^{2}<2$ (dark gray) and $\chi^{2}<1$ (light gray). (a) Erosivity constant, $k_{b}$, $\left(\mathrm{m}^{5 / 2} \mathrm{yr}^{2} \mathrm{~kg}^{-3 / 2}\right)$. (b) Modal grain size, $D(\mathrm{~cm})$. (c) Channel width exponent, $b_{w}$ (dimensionless). (d) Initial elevation, $E_{i}(\mathrm{~km})$. See Table 1 and section 3 for further explanation of parameters.

Monte Carlo searches using the incision onset and completion constraints and a $\chi^{2}$ comparison with the modern river profile. There are therefore two aspects of the uplift history that are explored using the "block uplift" Monte Carlo search: (1) the rates of uplift during the two stages of the first monoclonal uplift phase and (2) the timing of transition to block uplift.

[42] Good fit results found in the block uplift search have initial elevations between 1 and $2 \mathrm{~km}$ at $16 \mathrm{Ma}$ (Figure 11a), which is lower than in the two-stage and three-stage uplift searches. Many good fit simulations have uplift rates that are initially slow and start to increase between 10 and $8 \mathrm{Ma}$ for the second stage of the monoclinal uplift phase (Figure 11a). However, some good fit simulations have a steady uplift rate during the first phase. Transition to the block uplift phase occurs between 9.6 and $6.4 \mathrm{Ma}$, with later block uplift initiation (at 4.8 or $3.2 \mathrm{Ma}$ ) not yielding good fit results. Uplift rates are slower during the second uplift phase than the first. Based on the original constraints alone, these results indicate that the proposed block uplift scenario is equally successful as previous searches in fitting the incision observations. Importantly, this scenario identifies some scenarios with low plateau elevations $(<2.5 \mathrm{~km})$ that persist until at least $11 \mathrm{Ma}$, and a rapid uplift event between 11 and $6 \mathrm{Ma}$ that is consistent with the punctuated uplift model.

[43] However, simulations that are identified as "successful" by the existing constraints produce river profiles that do not compare well with the modern river profile, despite low $\chi^{2}$ values (Figure 11b). The change in uplift style results in the generation of knickpoints that are not fully transmitted through the catchment before the end of the simulations. In contrast, simulations that yield low $\chi^{2}$ values in the two-stage and three-stage uplift scenarios (Figures 8 and 10) have final river profiles that do not contain knickpoints and compare well with the modern river profile (Figure 3). The block uplift search was therefore unable to find a set of parameters that could both propagate the knickpoint upstream before the end of the

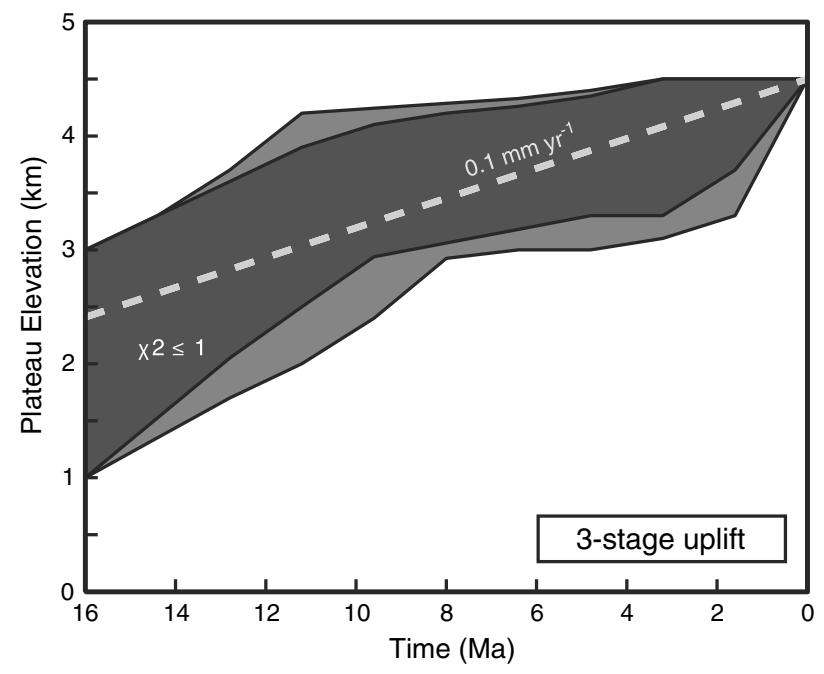

Figure 10. Past plateau elevations that fit both timing constraints with a $\chi^{2} \leq 1$ (light gray) and a $\chi^{2} \leq 2$ (dark gray) for simulations in which uplift is permitted to occur in three stages. Dashed gray line is a visual guide and indicates a steady uplift rate of $0.1 \mathrm{~mm} \mathrm{yr}^{-1}$. 

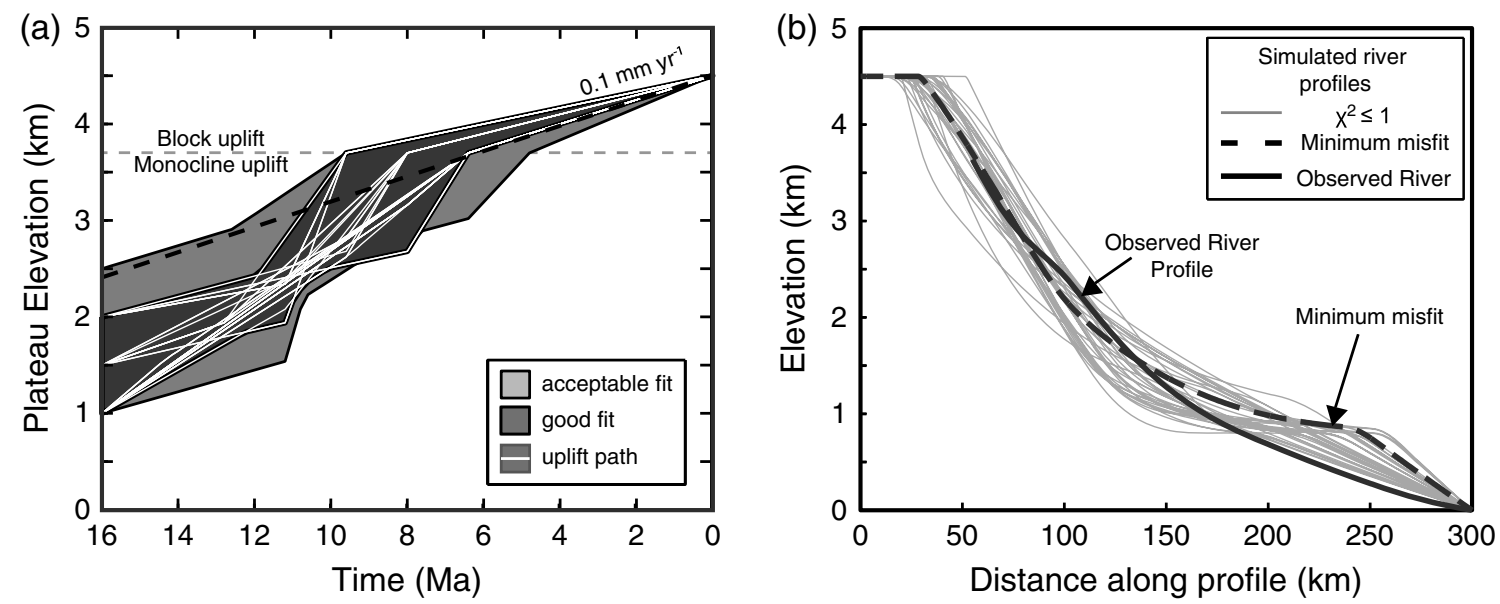

Figure 11. (a) Range of uplift histories that include a block uplift phase and that fit the timing constraints with a $\chi^{2}<1$ (white lines on dark gray region) and with a $\chi^{2}<2$ (light gray region). The horizontal dashed line at $3.7 \mathrm{~km}$ indicates the elevation at which uplift transitions from monoclinal to block uplift. An uplift rate of $0.1 \mathrm{~mm} \mathrm{yr}^{-1}$ is shown for reference. (b) Range of simulated river profiles that match the modern river profile (black) with a $\chi^{2}$ less than 1 in the block uplift simulations (Figure 11a). The final river profile with the lowest $\chi^{2}$ misfit found by the Monte Carlo search is shown in dashed black line. Note that most profiles found in this search contain a knickpoint that is not present in the observed river profile.

simulation and fit the timing constraints. There are two possible explanations for this: (1) the block uplift hypothesis is not able to explain the observations or (2) the current model formulation is too simple. In reality, for example, the plateau may have attained modern elevations before the present day or the transition from monoclinal to block uplift may not have been so abrupt. Future research efforts could explore variations on the block uplift model presented here to identify uplift rates and patterns that incorporate a component of block uplift and produce a better fit to the modern river profile.

\subsection{Role of Climate Change in Determining Incision Timing}

[44] A second aim of this study is to quantify the importance of paleoclimate and climate change to river incision processes. To the best of our knowledge, this study is unique in that it uses the results of a regional climate model as input to the river incision model and therefore accounts for both regional and orographic changes in climate. Here we describe the results of two additional Monte Carlo searches that were used to (1) demonstrate the importance of climate change through time and (2) test the sensitivity of the model to the magnitude of precipitation. In the first of these additional Monte Carlo searches, precipitation was held constant at a rate corresponding to the modern Andean elevation (100\%; Figure 3c) throughout each individual simulation in the same way as the climate sensitivity experiment (Figure 7). In the second search, precipitation rates are tied to elevation, as outlined in section 3.2, but the magnitude of discharge is reduced by $50 \%$ at all elevations.

[45] Lower plateau elevations prior to $\sim 10 \mathrm{Ma}$ are favored when precipitation rates are held constant (Figure 12a) than when precipitation rates increase with increasing elevation (Figure 8). The range of initial plateau elevations is restricted to $1-2.5 \mathrm{~km}$ under constant precipitation rates. Between 16 and $12 \mathrm{Ma}$, the upper bound of plateau elevations is $\sim 500 \mathrm{~m}$ lower when precipitation is held constant (Figures 8 and 12a). Furthermore, a large number of the good fit simulations are initiated at $2 \mathrm{~km}$ or less in the constant precipitation scenario, whereas scenarios with elevation-dependent precipitation rates were more commonly found to produce good fit scenarios when initiated at $2 \mathrm{~km}$ elevation or higher (Figure 9d). The lower bound on plausible plateau elevations is also lower prior to $\sim 6 \mathrm{Ma}$. After $\sim 6 \mathrm{Ma}$, a wider range of elevations are permitted when climate is not dependent on surface elevation. Because precipitation rates do not vary through time, changes in erosion potential are driven solely by changes in slope, which in turn are governed by the uplift history. Elevations greater than $3 \mathrm{~km}$ prior to $12 \mathrm{Ma}$ are not compatible with a modern climate because the combination of high slopes and high discharge drives rapid incision that breaks the incision onset constraint.

[46] Accounting for varying precipitation rates therefore alters the interpretation of surface uplift histories from records of river incision. Paleo-elevation estimates that account for increasing precipitation rates can be up to $500 \mathrm{~m}$ higher than estimates based on the modern precipitation distribution. Coupled climatic and tectonic changes both contribute significantly to the evolution of the river profile. Time-variant precipitation rates modify erosion potential and, consequently, the response time of the system to perturbations [Whipple, 2001]. Note that it is possible to identify river profile evolution scenarios that are consistent with the slow and steady end-member model of Andean uplift even when a modern climate regime is assumed (Figure 12a).

[47] In the second climate sensitivity experiment, we test the sensitivity of the model to discharge magnitudes using a Monte Carlo search with $50 \%$ less discharge (Figure 12b). This sensitivity experiment addresses two uncertainties in the original model formulation. First, infiltration and evaporation rates were not accounted for in the original Monte Carlo search (Figure 8) and all precipitation is assumed to become surface runoff. Second, the experiment addresses uncertainties in the climate model inputs to the river simulations. River incision is sensitive to both 

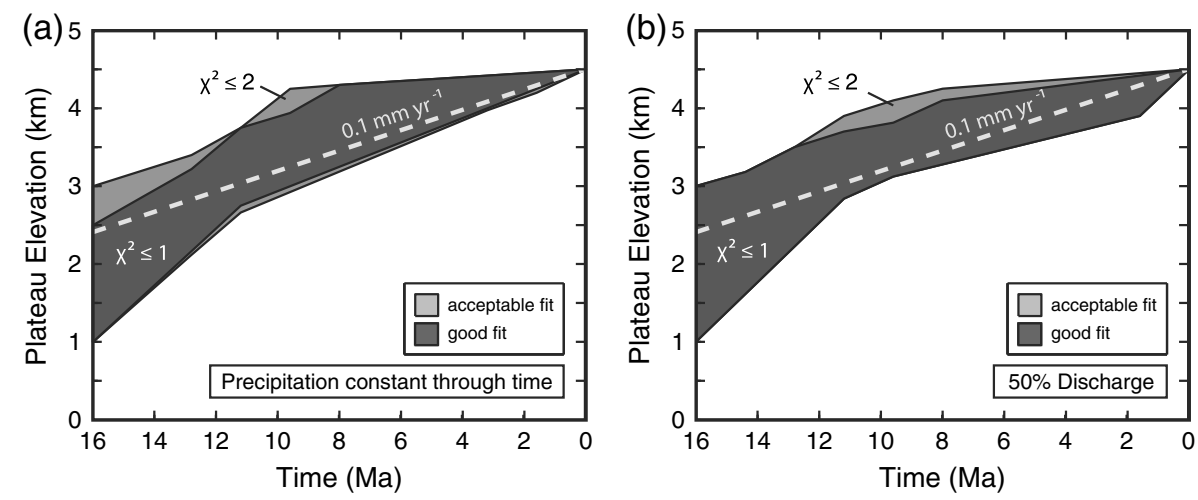

Figure 12. Past plateau elevations that fit both timing constraints with a $\chi^{2} \leq 2$ (light gray) and a $\chi^{2} \leq 1$ (dark gray) for simulations in which (a) precipitation rate is held constant through time at a rate corresponding to $100 \%$ Andes elevation (Figure 3c) and (b) discharge is reduced to 50\% compared with the original search (Figure 8 ). The dashed gray line is a visual guide and indicates a steady uplift rate of $0.1 \mathrm{~mm} \mathrm{yr}^{-1}$.

the magnitude and spatial distribution of precipitation [Roe et al., 2002]. In comparison with modern observations, RegCM overestimates the magnitude of precipitation over South America for the modern climate, but simulates the spatial distribution of precipitation well (Figure 2) [Insel et al., 2010]. The simulated increase in precipitation with increasing plateau elevation is consistent with similar studies using climate models with different resolutions and precipitation parameterization [Insel et al., 2012; Jeffery et al., 2012]. Paleoclimate simulation results are supported by sedimentological evidence from northern Chile $\left(19^{\circ} \mathrm{S}-21^{\circ} \mathrm{S}\right)$ that indicates precipitation rates on the western edge of the Altiplano have increased since the middle Miocene whereas the coastal regions have experienced continued aridity [Schlunegger et al., 2010]. The largest uncertainty in climate model inputs is therefore considered to be the magnitude of precipitation and the fraction that becomes river discharge, which is addressed using the $50 \%$ discharge experiment.

[48] Reducing the magnitude of discharge has a limited impact on the range of surface uplift histories (Figures 8 and 12b). Between 16 and $11 \mathrm{Ma}$, the lower limit of uplift ranges is up to $500 \mathrm{~m}$ lower in the $50 \%$ discharge case, with the maximum difference at the beginning of the simulation (16 Ma). However, only three uplift histories that were initiated with a plateau elevation $<2.5 \mathrm{~km}$ gave a good fit to the model constraints. The upper limit on uplift ranges in the two scenarios is very similar throughout the simulation period (Figures 8 and 12). We note that this minimal effect of changing precipitation magnitudes from the climate model on the river profiles is due to the fact that the erosion parameters, such as $k_{b}$ (equation (6)), offset the effect of discharge magnitude.

[49] Extraction of uplift histories from river profiles is sensitive to both the temporal distribution and the magnitude of the assumed precipitation. In catchments where precipitation rates increase with increasing regional topography, such as the Ocoña, overestimating the magnitude of precipitation can result in an underestimation of the minimum elevation. Furthermore, ignoring the increase in precipitation rates with increasing topographic elevation can result in the underestimation of the maximum elevation. However, given the large uncertainties in river erosion parameterization, there is significant overlap in good fit uplift histories under the three different climatic scenarios considered here (Figures 8 and 12). The range of uplift histories established in the original Monte Carlo search (Figure 8) is therefore considered robust with respect to the uncertainties in climate model-derived inputs to the model.

\subsection{Model Validation and Sensitivity of Results to Model Formulation}

[50] As with any modeling study, the simulations presented here include simplifications and assumptions. Geological factors that are not explicitly accounted for in the model include drainage re-organization, lithological variations, volcanic valley infill, mass wasting, and glaciation. The model also assumes that the river is governed by detachment-limited erosion and sediment flux is not explicitly accounted for. In order to validate our results, we examine and when possible quantify the impact of these factors on the range of acceptable plateau histories identified by the model.

\subsubsection{Drainage Area}

[51] Conceivable changes to the catchment area include capture of the upper branches (Cotahuasi or Maran canyons; Figure 1) and growth of the catchment by headward erosion. Capture of a drainage area similar in magnitude to the Cotahuasi branch would result in a step increase in discharge and trigger an increase in erosion rate that would propagate upstream. A drainage capture event could drive a rapid increase in incision rate and is an alternative to rapid surface uplift as a driver of incision. However, at present there is no direct evidence for a drainage capture event within this catchment. Similarly, drainage area increase by headward erosion would progressively increase the total discharge at a point on the profile. If the increase in erosional capacity causes the flow to exceed the erosion threshold, active incision would be initiated. Both of the catchment area scenarios are consistent with our key finding that the observed pulse of river incision does not necessitate low plateau elevations in the mid-Miocene.

\subsubsection{Catchment Properties}

[52] A wide range of values for the erosivity constant $\left(k_{b}\right)$ was included in the Monte Carlo search (Table 1). However, 
for each simulation, the selected value was held constant in space and time. This model formulation assumes that the underlying lithology is uniform throughout the catchment, which in reality is not the case (see the auxiliary material). Elsewhere on the western Andean flank, Abbuehl et al. [2011] find evidence for incision through an erosionresistant caprock that delayed faster incision into the weaker, underlying rocks. However, the main lithological transition encountered by the Ocoña river was from the conglomeratic Moquegua group to the stronger, intrusive Paleozoic-Mesozoic basement. This transition may have slowed incision but did not stop it as $>1 \mathrm{~km}$ of basement rock has been incised in the middle reaches.

\subsubsection{Erosion Law}

[53] This study uses a simple stream-power based erosion law with an effective linear exponent. However, plausible uplift histories are not sensitive to the choice of exponent (a) in the erosion law (equations (1a) and (1b)). A Monte Carlo search performed with $a=5 / 2$ (not shown), consistent with erosion by suspended load abrasion, found good-fit uplift histories that are very similar to those found with $a=3 / 2$. Good fit simulations found with $a=5 / 2$ had a lower critical shear stress range than with $a=3 / 2$.

[54] The model used in this study assumes that erosion is detachment limited. That is, incision is limited by the ability of the river to detach material from the bed. Influx of material to the valley by mass wasting or volcanic debris is not explicitly accounted for. The use of an erosion threshold term partly accounts for the need to transport a sediment load, but does not account for temporal variation in the amount of sediment cover or the function of sediment load as an erosion tool [Sklar and Dietrich, 1998]. The incorporation of an erosion threshold also maintains fluvial relief long after the cessation of or a severe reduction in tectonic uplift. When a simple detachment-limited model is used, a very low uplift rate would drive the system to asymptotically approach an unrealistically low slope at each node. Including a threshold prevents this behavior as the system is driven toward a slope at which the local shear stress equals the erosion threshold. We therefore use a model with an erosion threshold term in part to acknowledge that significant relief is retained for long periods in tectonically quiescent river systems, e.g., Appalachians or Caledonides. Whipple and Tucker [2002] outlined the behavior of transport- and detachment-limited systems and we apply their findings to the Ocoña catchment and explore the implications of using a detachment-limited model as follows.

[55] (1) Transition to a transport-limited system is likely when uplift slows and the river approaches steady state, and transient conditions can be difficult to detect based on river profiles. Low incision rates in the last $\sim 2 \mathrm{Ma}$ suggest that the lower reaches of the Ocoña catchment are approaching steady state. Combined with observations of high sediment production through landsliding in the upper canyon reaches, it is likely that some of the river is now behaving as a transport-limited system, particularly downstream of the major Maran-Cotahuasi confluence.

[56] (2) Detachment-limited systems adjust to changes in base level by upstream propagation of a knickpoint whereas transport-limited systems tend to undergo more uniform lowering and knickpoints, where present, are more diffuse. Our conclusions are dependent on the incision timing, which we have assumed to occur under detachment-limited conditions. This assumption is supported by two lines of evidence: (1) there is exposed bedrock in the Maran branch of the modern river and (2) apatite ${ }^{4} \mathrm{He} /{ }^{3} \mathrm{He}$ thermochronometry data are consistent with the propagation of an incisional wave [Schildgen et al., 2010], which is more consistent with a detachment-limited, rather than transportlimited system [Whipple and Tucker, 2002]. The importance of sediment flux to river incision is likely to have increased through time as uplift and incision rates have slowed. A change in uplift rate during the last $~ 5$ Myr may not be evident in the modern topography if incision response times have increased since the late Miocene due to a transition from detachment to transport-limited conditions. Indeed, there is no evidence in the river profile of estimates of $\sim 300 \mathrm{~m}$ of coastal uplift since $\sim 800 \mathrm{ka}$ inferred from coastal morphology [Regard et al., 2010].

\subsection{Monte Carlo Search as a Tool for Interrogating River Profile Evolution}

[57] In this study, we have demonstrated a Monte Carlo approach to extract uplift history from river profiles under a climate regime that is dependent on the orogen topography. Although the Monte Carlo search process did not identify a unique uplift history, it did succeed in (1) differentiating between uplift histories that were plausible under different climatic conditions and (2) constraining the erosion parameters that could yield a good fit to observations. Furthermore, we show that the surface uplift history can be constrained in cases where river properties such as channel widths, erosivity, and erosion mechanism are not well known. Because many of the parameters are not well known, most uplift histories could produce the modern river profile (Figure 8). Additional constraints on the timing of incision were necessary to reduce the range of plausible uplift histories sufficiently for the results to be useful. Application of this method is therefore restricted to regions where information is available on the initial conditions and timing of incision from, for example, thermochronometry data. Better constraints on the appropriate erosion rule could better constrain surface uplift histories in the Ocoña catchment.

\section{Conclusions}

[58] In order to determine surface uplift histories of orogens from observations of river incision, it is necessary to account for spatial and temporal gradients in precipitation. By using a regional climate model, it is possible to account for changes in regional climate associated with mountain belt development in addition to local orographic effects. This is particularly important on the leeward side of mountain ranges, such as the Ocoña canyon, because simple orographic models would predict a reduction in precipitation with increasing elevation.

[59] River simulations with a Monte Carlo search successfully constrain a range of uplift histories and erosion parameters that are consistent with geological observations. In addition to the shape of the modern river profile, constraints on the timing and magnitude of incision were necessary to define a meaningful uplift history. Furthermore, the identification of the full range of good fit uplift scenarios 
requires the inclusion of an erosion threshold in the model. Our results show that high magnitudes of incision do not necessitate contemporaneous, rapid, surface uplift but that a combination of climate change and surface uplift can drive rapid river incision when erosion thresholds are attained.

[60] Uplift histories of the northern Andean plateau constrained by canyon incision are compatible with either a slow and steady or punctuated surface uplift model. Arguments that canyon incision indicates rapid surface uplift are therefore not unique to geologically constrained models of river dynamics. Future work that limits the erosion parameter space will improve this technique's ability to distinguish between different uplift scenarios.

[61] Acknowledgments. This work was funded by grants to T.A.E. and C.J.P. from the U.S. National Science Foundation (EAR awards 0738822 and 0907817 ). M.L.J. was also supported by a Fellowship from the German DAAD. N. Insel is thanked for providing access to the RegCM paleoprecipitation results. We are grateful for comments by P. van der Beek, D. Lague, K.X. Whipple, and an anonymous reviewer on an earlier version of this manuscript. The ASTER DEM data were obtained through the online Data Pool at the NASA Land Processes Distributed Active Archive Center (LP DAAC), USGS/Earth Resources Observation and Science (EROS) Center, Sioux Falls, South Dakota (http://lpdaac.usgs.gov/get_data). The geological map of Peru was obtained from the website of the Instituto Geológico Minero y Metalúrgico (INGEMMET) at http://www.ingemmet. gob.pe/form/plantilla01.aspx?Opcion=184.

\section{References}

Abbuehl, L. M., K. P. Norton, J. D. Jansen, F. Schlunegger, A. Aldahan, and G. Possnert (2011), Erosion rates and mechanisms of knickzone retreat inferred from (10)Be measured across strong climate gradients on the northern and central Andes Western Escarpment, Earth Surf. Processes Landforms, 36, 1464-1473, doi:10.1002/esp.2164.

Attal, M., G. E. Tucker, A. C. Whittaker, P. A. Cowie, and G. P. Roberts (2008), Modeling fluvial incision and transient landscape evolution: Influence of dynamic channel adjustment, J. Geophys. Res. Earth Surf., 113, F03013, doi:10.1029/2007JF000893.

Barke, R., and S. Lamb (2006), Late Cenozoic uplift of the Eastern Cordillera, Bolivian Andes, Earth Planet. Sci. Lett., 249, 350-367, doi:10.1016/ j.eps1.2006.07.012.

Barnes, J. B., and T. A. Ehlers (2009), End member models for Andean Plateau uplift, Earth Sci. Rev., 97, 105-132, doi:10.1016/j. earscirev.2009.08.003.

Barnes, J. B., T. A. Ehlers, N. McQuarrie, P. B. O'Sullivan, and J. D. Pelletier (2006), Eocene to recent variations in erosion across the central Andean fold-thrust belt, northern Bolivia: Implications for plateau evolution, Earth Planet. Sci. Lett., 248, 118-133, doi:10.1016/j.eps1.2006.05.018.

Barnes, J. B., T. A. Ehlers, N. McQuarrie, P. B. O'Sullivan, and S. Tawackoli (2008), Thermochronometer record of central Andean plateau growth, Bolivia (19.5 S), Tectonics, 27, TC3003, doi:10.1029/2007TC002174.

Bookhagen, B., and M. R. Strecker (2008), Orographic barriers, highresolution TRMM rainfall, and relief variations along the eastern Andes, Geophys. Res. Lett., 35, L06403, doi:10.1029/2007GL032011.

Bookhagen, B., and M. R. Strecker (2012), Spatiotemporal trends in erosion rates across a pronounced rainfall gradient: Examples from the southern central Andes, Earth Planet. Sci. Lett., 327, 97-110, doi:10.1016/j.epsl.2012.02.005.

Campetella, C. M., and C. S. Vera (2002), The influence of the Andes mountains on the South American low-level, Geophys. Res. Lett., 29(17), 1826, doi:10.1029/2002GL015451.

Clark, M. K., L. M. Schoenbohm, L. H. Royden, K. X. Whipple, B. C. Burchfiel, X. Zhang, W. Tang, E. Wang, and L. Chen (2004), Surface uplift, tectonics, and erosion of eastern Tibet from large-scale drainage patterns, Tectonics, 23, TC1006, doi:10.1029/2002TC001402.

Crosby, B. T., and K. X. Whipple (2006), Knickpoint initiation and distribution within fluvial networks: 236 waterfalls in the Waipaoa River, North Island, New Zealand, Geomorphology, 82, 16-38, doi:10.1016/j. geomorph.2005.08.023.

DeCelles, P. G., and B. K. Horton (2003), Early to middle Tertiary foreland basin development and the history of Andean crustal shortening in Bolivia, Geol. Soc. Am. Bull., 115(1), 58-77, doi:10.1130/0016-7606 (2003) $115<0058:$ ETMTFB $>2.0$. CO; 2 .
Decou, A., H. von Eynatten, M. Mamani, T. Sempere, and G. Woerner (2011), Cenozoic forearc basin sediments in Southern Peru $\left(15-18^{\circ} \mathrm{S}\right)$ : Stratigraphic and heavy mineral constraints for Eocene to Miocene evolution of the Central Andes, Sediment. Geol., 237, 55-72, doi:10.1016/j. sedgeo.2011.02.004.

Duvall, A., E. Kirby, and D. Burbank (2004), Tectonic and lithologic controls on bedrock channel profiles and processes in coastal California, J. Geophys. Res. Earth Surf., 109, F03002, doi:10.1029/ 2003JF000086.

Ehlers, T. A., and C. J. Poulsen (2009), Influence of Andean uplift on climate and paleoaltimetry estimates, Earth Planet. Sci. Lett., 281, 238-248, doi:10.1016/j.eps1.2009.02.026.

Farias, M., R. Charrier, D. Comte, J. Martinod, and G. Herail (2005), Late Cenozoic deformation and uplift of the western flank of the Altiplano: Evidence from the depositional, tectonic, and geomorphologic evolution and shallow seismic activity (northern Chile at $19^{\circ} 30^{\prime} \mathrm{S}$ ), Tectonics, 24, TC4001, doi:10.1029/2004TC001667.

Farias, M., R. Charrier, S. Carretier, J. Martinod, A. Fock, D. Campbell, J. Caceres, and D. Comte (2008), Late Miocene high and rapid surface uplift and its erosional response in the Andes of central Chile $\left(33^{\circ} \mathrm{S}-35^{\circ} \mathrm{S}\right)$, Tectonics, 27, TC1005, doi:10.1029/2006TC002046.

Foley, M. G. (1980), Bed-rock incision by streams, Geol. Soc. Am. Bull., 91, 2189-2213, doi:10.1130/GSAB-P2-91-2189.

Frailey, C. D., E. L. Lavina, A. Rancy, and J. P. de Souza Filho (1988), A proposed Pleistocene/Holocene lake in the Amazon basin and its significance to Amazonian geology and biogeography, Acta Amazonica, 18, 119-143.

Garcia, M., R. Riquelme, M. Farias, G. Herail, and R. Charrier (2011), Late Miocene-Holocene canyon incision in the western Altiplano, northern Chile: Tectonic or climatic forcing?, J. Geol. Soc., 168, 1047-1060, doi:10.1144/0016-76492010-134.

Garreaud, R. D. (1999), Multiscale analysis of the summertime precipitation over the central Andes, Mon. Weather Rev., 127, 901-921, doi:10.1175/ 1520-0493(1999)127<0901:maotsp > 2.0.co;2.

Garreaud, R. D., M. Vuille, and A. C. Clement (2003), The climate of the Altiplano: Observed current conditions and mechanisms of past changes, Palaeogeogr. Palaeoclimatol. Palaeoecol., 194(1-3), 5-22, doi:10.1016/ s0031-0182(03)00269-4.

Garzione, C. N., P. Molnar, J. C. Libarkin, and B. J. MacFadden (2006), Rapid late Miocene rise of the Bolivian Altiplano: Evidence for removal of mantle lithosphere, Earth Planet. Sci. Lett., 241, 543-556, doi:10.1016/j.eps1.2005.11.026.

Garzione, C. N., G. D. Hoke, J. C. Libarkin, S. Withers, B. MacFadden, J. Eiler, P. Ghosh, and A. Mulch (2008), Rise of the Andes, Science, 320, 1304-1307, doi:10.1126/science.1148615.

Ghosh, P., C. N. Garzione, and J. M. Eiler (2006), Rapid uplift of the Altiplano revealed through C-13-O-18 bonds in paleosol carbonates, Science, 311, 511-515, doi:10.1126/science.1119365.

Gotberg, N., N. McQuarrie, and V. C. Caillaux (2010), Comparison of crustal thickening budget and shortening estimates in southern Peru $\left(12-14^{\circ} \mathrm{S}\right)$ : Implications for mass balance and rotations in the "Bolivian orocline", Geol. Soc. Am. Bull., 122, 727-742, doi:10.1130/b26477.1.

Gubbels, T. L., B. L. Isacks, and E. Farrar (1993), High-level surfaces, plateau uplift, and foreland development, Bolivian central Andes, Geology, 21, 695-698, doi:10.1130/0091-7613(1993)021 < 0695:HLSPUA > 2.3.CO;2.

Gunnell, Y., J. C. Thouret, S. Brichau, A. Carter, and K. Gallagher (2010), Low-temperature thermochronology in the Peruvian central Andes: Implications for long-term continental denudation, timing of plateau uplift, canyon incision and lithosphere dynamics, J. Geol. Soc., 167, 803-815, doi:10.1144/0016-76492009-166.

Hack, J. T. (1957), Studies of longitudinal stream profiles in Virginia and Maryland, U.S. Geol. Surv. Prof. Pap., 294-B, 45-97.

Hall, S. R., D. L. Farber, L. Audin, and R. C. Finkel (2012), Recently active contractile deformation in the forearc of southern Peru, Earth Planet. Sci. Lett., 337-338, 85-92, doi:10.1016/j.eps1.2012.04.007.

Hancock, G. S., R. S. Anderson, and K. X. Whipple (1998), Beyond power: Bedrock river incision process and form, in Rivers Over Rock: Fluvial Processes in Bedrock Channels, edited by K. Tinkler, and E. E. Wohl, pp. 35-60, AGU, Washington, D.C.

Hartley, A. J., T. Sempere, and G. Worner (2007), A comment on "Rapid late Miocene rise of the Bolivian Altiplano: Evidence for removal of mantle lithosphere" by C.N. Garzione et al. Earth Planet. Sci. Lett. 241 (2006) 543-556, Earth Planet. Sci. Lett., 259, 625-629, doi:10.1016/j. epsl.2007.04.012.

Hoke, G. D., and C. N. Garzione (2008), Paleosurfaces, paleoelevation, and the mechanisms for the late Miocene topographic development of the Altiplano plateau, Earth Planet. Sci. Lett., 271(1-4), 192-201, doi:10.1016/ j.epsl.2008.04.008.

Hoke, G. D., B. L. Isacks, T. E. Jordan, N. Blanco, A. J. Tomlinson, and J. Ramezani (2007), Geomorphic evidence for post-10 Ma uplift of the 
western flank of the central Andes $18^{\circ} 30^{\prime}-22^{\circ} \mathrm{S}$, Tectonics, 26, TC5021, doi:10.1029/2006TC002082.

Houston, J., and A. J. Hartley (2003), The central Andean west-slope rainshadow and its potential contribution to the origin of hyper-aridity in the Atacama desert, Int. J. Climatol., 23(12), 1453-1464, doi:10.1002/joc.938.

Howard, A. D., and G. Kerby (1983), Channel changes in badlands, Geol. Soc. Am. Bull., 94, 739-752, doi:10.1130/0016-7606.

Howard, A. D., W. E. Dietrich, and M. A. Seidl (1994), Modeling fluvial erosion on regional to continental scales, J. Geophys. Res. Solid Earth, 99, 13,971-13,986, doi:10.1029/94JB00744.

Huffman, G. J., R. F. Adler, D. T. Bolvin, G. Gu, E. J. Nelkin, K. P. Bowman, Y. Hong, E. F. Stocker, and D. B. Wolff (2007), The TRMM Multisatellite Precipitation Analysis (TMPA): Quasi-global, multiyear, combined-sensor precipitation estimates at fine scales, J. Hydrometeorol., 8, 38-55, doi:10.1175/JHM560.1.

Instituto Geológico Minero y Metalúrgico (2004), Carta Geológica Nacional del Perú, Instituto Geologico Minero y Metalurgico (INGEMMET)

Insel, N., C. J. Poulsen, and T. A. Ehlers (2010), Influence of the Andes Mountains on South American moisture transport, convection, and precipitation, Clim. Dyn., 35, 1477-1492, doi:10.1007/s00382-009. 0637-1.

Insel, N., C. J. Poulsen, T. A. Ehlers, and C. Sturm (2012), Response of meteoric $\delta^{18} \mathrm{O}$ to surface uplift-Implications for Cenozoic Andean Plateau growth, Earth Planet. Sci. Lett., 317-318, 262-272, doi:10.1016/j. eps1.2011.11.039.

Isacks, B. L. (1988), Uplift of the central Andean plateau and bending of the Bolivian orocline, J. Geophys. Res. Solid Earth Planets, 93, 3211-3231, doi:10.1029/JB093iB04p03211.

Jeffery, M. L., C. J. Poulsen, and T. A. Ehlers (2012), Impacts of Cenozoic global cooling, surface uplift, and an inland seaway on South American paleoclimate and precipitation $\delta^{18} \mathrm{O}$, Geol. Soc. Am. Bull., 124, 335-351, doi:10.1130/B30467.1.

Kennan, L., S. H. Lamb, and L. Hoke (1997), High-altitude paleosurfaces in the Bolivian Andes: Evidence for late Cenozoic uplift, in Special Publication of the Geological Society of London, edited by M. Widdowson, The Geological Society, London, pp. 307-323, doi:10.1144/GSL. SP.1997.120.01.20.

Kirby, E., and K. X. Whipple (2001), Quantifying differential rock-uplift rates via stream profile analysis, Geology, 29, 415-418, doi:10.1130/ 0091-7613(2001)029<0415:QDRURV > 2.0.CO;2.

Kober, F., F. Schlunegger, G. Zeilinger, and H. Schneider (2006), Surface uplift and climate change: The geomorphic evolution of the Western Escarpment of the Andes of northern Chile between the Miocene and present, in Tectonics, Climate, and Landscape Evolution, edited by S. D. Willett, N. Hovius, M. T. Brandon, and D. M. Fisher, pp. 75-86, Geological Soc Amer Inc, Boulder.

Kober, F., S. Ivy-Ochs, F. Schlunegger, H. Baur, P. W. Kubik, and R. Wieler (2007), Denudation rates and a topography-driven rainfall threshold in northern Chile: Multiple cosmogenic nuclide data and sediment yield budgets, Geomorphology, 83, 97-120, doi:10.1016/j. geomorph.2006.06.029.

Kutzbach, J. E., P. J. Guetter, W. F. Ruddiman, and W. L. Prell (1989), Sensitivity of climate to late Cenozoic uplift in Southern Asia and the American West: Numerical experiments, J. Geophys. Res., 94, 18393-18407, doi:10.1029/JD094iD15p18393.

Lague, D., N. Hovius, and P. Davy (2005), Discharge, discharge variability, and the bedrock channel profile, J. Geophys. Res. Earth Surf., 110, F04006, doi:10.1029/2004JF000259.

Lamb, S. (2011), Did shortening in thick crust cause rapid late Cenozoic uplift in the northern Bolivian Andes?, J. Geol. Soc., 168, 1079-1092, doi:10.1144/0016-76492011-008.

Lave, J., and J. P. Avouac (2001), Fluvial incision and tectonic uplift across the Himalayas of central Nepal, J. Geophys. Res. Solid Earth, 106, 26561-26591, doi:10.1029/2001JB000359.

Lenters, J. D., and K. H. Cook (1995), Simulation and diagnosis of the regional summertime precipitation climatology of South America, $J$. Climate, 8, 2988-3005, doi:10.1175/1520-0442(1995)008<2988: SADOTR $>2.0 . \mathrm{CO} ; 2$.

Leopold, L. B., and T. Maddock (1953), The hydraulic geometry of stream channels and some physiographic implications, U.S. Geol. Surv. Prof. Pap., 252, 56.

McQuarrie, N. (2002), The kinematic history of the central Andean foldthrust belt, Bolivia: Implications for building a high plateau, Geol. Soc. Am. Bull., 114(8), 950-963, doi:10.1130/0016-7606(2002)114<0950: TKHOTC $>2.0 . \mathrm{CO} ; 2$.

McQuarrie, N., J. B. Barnes, and T. A. Ehlers (2008a), Geometric, kinematic, and erosional history of the central Andean Plateau, Bolivia (15-17 ${ }^{\circ}$ S), Tectonics, 27, TC3007, doi:10.1029/2006TC002054.
McQuarrie, N., T. A. Ehlers, J. B. Barnes, and B. Meade (2008b), Temporal variation in climate and tectonic coupling in the central Andes, Geology, 36, 999-1003, doi:10.1130/g25124a.1.

McQuarrie, N., B. K. Horton, G. Zandt, S. Beck, and P. G. DeCelles (2005), Lithospheric evolution of the Andean fold-thrust belt, Bolivia, and the origin of the central Andean plateau, Tectonophysics, 399, 15-37, doi:10.1016/j.tecto.2004.12.013.

METI, and NASA (2001), ASTER GDEM edited, Ministry of Economy, Trade and Industry (METI) and NASA Land Processes Distributed Active Archive Center (LP DAAC), USGS/Earth Resources Observation and Science (EROS) Center, Sioux Falls, South Dakota.

Montgomery, D. R., and K. B. Gran (2001), Downstream variations in the width of bedrock channels, Water Resour. Res., 37, 1841-1846, doi:10.1029/2000wr900393.

Muñoz, N., and R. Charrier (1996), Uplift of the western border of the Altiplano on a west-vergent thrust system, northern Chile, J. S. Am. Earth Sci., 9, 171-181, doi:10.1016/0895-9811(96)00004-1.

Poulsen, C. J., T. A. Ehlers, and N. Insel (2010), Onset of convective rainfall during gradual late Miocene rise of the central Andes, Science, 328, 490-493, doi:10.1126/science. 1185078 .

Quade, J., C. Garzione, and J. Eiler (2007), Paleoelevation reconstruction using pedogenic carbonates, in Paleoaltimetry: Geochemical and Thermodynamic Approaches, edited by M. J. Kohn, pp. 53-87, doi:10.2139/ rmg.2007.66.3.

Rasanen, M. E., A. M. Linna, J. C. R. Santos, and F. R. Negri (1995), Late Miocene tidal deposits in the Amazonian foreland basin, Science, 269, 386-390, doi:10.1126/science.269.5222.386.

Regard, V., M. Saillard, J. Martinod, L. Audin, S. Carretier, K. Pedoja, R. Riquelme, P. Paredes, and G. Herail (2010), Renewed uplift of the central Andean forearc revealed by coastal evolution during the Quaternary, Earth Planet. Sci. Lett., 297, 199-210, doi:10.1016/j.epsl.2010.06.020.

Rigon, R., I. Rodriguez-Iturbe, A. Maritan, A. Giacometti, D. G. Tarboton, and A. Rinaldo (1996), On Hack's law, Water Resour. Res., 32, 3367-3374, doi:10.1029/96WR02397.

Roe, G. H. (2005), Orographic precipitation, Annu. Rev. Earth Planet. Sci., 33, 645-671, doi:10.1146/annurev.earth.33.092203.122541.

Roe, G. H., D. R. Montgomery, and B. Hallet (2002), Effects of orographic precipitation variations on the concavity of steady-state river profiles, Geology, 30(2), 143-146, doi:10.1130/0091-7613(2002)030<0143: eoopvo $>2.0 . \mathrm{co} ; 2$.

Roe, G. H., D. R. Montgomery, and B. Hallet (2003), Orographic precipitation and the relief of mountain ranges, J. Geophys. Res. Solid Earth, 108(B6), 2315, doi:10.1029/2001jb001521.

Roperch, P., T. Sempere, O. Macedo, C. Arriagada, M. Fornari, C. Tapia, M. Garcia, and C. Laj (2006), Counterclockwise rotation of late Eocene-Oligocene fore-arc deposits in southern Peru and its significance for oroclinal bending in the central Andes, Tectonics, 25, TC3010, doi:10.1029/2005tc001882.

Schildgen, T. F., G. Balco, and D. L. Shuster (2010), Canyon incision and knickpoint propagation recorded by apatite $\mathrm{He}-4 / \mathrm{He}-3$ thermochronometry, Earth Planet. Sci. Lett., 293, 377-387, doi:10.1016/j.eps1.2010.03.009.

Schildgen, T. F., K. V. Hodges, K. X. Whipple, P. W. Reiners, and M. S. Pringle (2007), Uplift of the western margin of the Andean plateau revealed from canyon incision history, southern Peru, Geology, 35, 523-526, doi:10.1130/g23532a.1.

Schildgen, T. F., K. V. Hodges, K. X. Whipple, M. S. Pringle, M. van Soest, and K. Cornell (2009a), Late Cenozoic structural and tectonic development of the western margin of the central Andean Plateau in southwest Peru, Tectonics, 28, TC4007, doi:10.1029/2008tc002403.

Schildgen, T. F., T. A. Ehlers, D. M. Whipp, M. C. van Soest, K. X. Whipple, and K. V. Hodges (2009b), Quantifying canyon incision and Andean Plateau surface uplift, southwest Peru: A thermochronometer and numerical modeling approach, J. Geophys. Res. Earth Surf., 114, F04014, doi:10.1029/2009jf001305.

Schlunegger, F., K. P. Norton, and G. Zeilinger (2011), Climatic forcing on channel profiles in the eastern cordillera of the Coroico Region, Bolivia, J. Geol., 119, 97-107, doi:10.1086/657407.

Schlunegger, F., F. Kober, G. Zeilinger, and R. von Rotz (2010), Sedimentology-based reconstructions of paleoclimate changes in the Central Andes in response to the uplift of the Andes, Arica region between 19 and $21^{\circ} \mathrm{S}$ latitude, northern Chile, Int. J. Earth Sci., 99, 123-137, doi:10.1007/s00531-010-0572-8.

Schlunegger, F., G. Zeilinger, A. Kounov, F. Kober, and B. Husser (2006), Scale of relief growth in the forearc of the Andes of Northern Chile (Arica latitude, $18^{\circ} \mathrm{S}$ ), Terra Nova, 18, 217-223, doi:10.1111/j.1365-3121.2006. 00682.x.

Seidl, M. A., and W. E. Dietrich (1992), The problem of channel erosion into bedrock, in Catena Supplement 23, edited by K. H. Schmidt, and J. de Ploey, Catena Verlag, Reiskirchen, Germany, pp. 101-124. 


\section{JEFFERY ET AL.: PALEOCLIMATE ROLE IN RIVER INCISION}

Simpson, G. (2004), Role of river incision in enhancing deformation, Geology, 32, 341-344, doi:10.1130/g20190.1.

Sklar, L. S., and W. E. Dietrich (1998), River longitudinal profiles and bedrock incision models: stream power and the influence of sediment supply, in Rivers Over Rock: Fluvial Processes in Bedrock Channels, edited by K. J. Tinkler, and E. E. Wohl, AGU, Washington, DC, pp. 237-260.

Sklar, L. S., and W. E. Dietrich (2004), A mechanistic model for river incision into bedrock by saltating bed load, Water Resour. Res., 40, W06301, doi:10.1029/2003WR002496.

Snyder, N. P., K. X. Whipple, G. E. Tucker, and D. J. Merritts (2000), Landscape response to tectonic forcing: Digital elevation model analysis of stream profiles in the Mendocino triple junction region, northern California, Geol. Soc. Am. Bull., 112, 1250-1263, doi:10.1130/0016-7606 (2000) $112<1250:$ :LRTFD $>2.0$. CO; 2

Snyder, N. P., K. X. Whipple, G. E. Tucker, and D. J. Merritts (2003), Importance of a stochastic distribution of floods and erosion thresholds in the bedrock river incision problem, J. Geophys. Res. Solid Earth, 108(B2), 2117, doi:10.1029/2001JB001655.

Stock, J. D., and D. R. Montgomery (1999), Geologic constraints on bedrock river incision using the stream power law, J. Geophys. Res. Solid Earth, 104, 4983-4993, doi:10.1029/98JB02139.

Strecker, M. R., R. Alonso, B. Bookhagen, B. Carrapa, I. Coutand, M. P. Hain, G. E. Hilley, E. Mortimer, L. Schoenbohm, and E. R. Sobel (2009), Does the topographic distribution of the central Andean Puna Plateau result from climatic or geodynamic processes?, Geology, 37, 643-646, doi:10.1130/G25545A.1.

Thouret, J. C., G. Woerner, Y. Gunnell, B. Singer, X. Zhang, and T. Souriot (2007), Geochronologic and stratigraphic constraints on canyon incision and Miocene uplift of the Central Andes in Peru, Earth Planet. Sci. Lett., 263, 151-166, doi:10.1016/j.eps1.2007.07.023.

Tucker, G. E. (2004), Drainage basin sensitivity to tectonic and climatic forcing: Implications of a stochastic model for the role of entrainment and erosion thresholds, Earth Surf. Processes Landforms, 29, 185-205, doi:10.1002/esp.1020.

Tucker, G. E., and R. Slingerland (1997), Drainage basin responses to climate change, Water Resour. Res., 33, 2031-2047, doi:10.1029/97WR00409.

Victor, P. (2004), Uplift of the western Altiplano plateau: Evidence from the Precordillera between $20^{\circ}$ and $21^{\circ} \mathrm{S}$ (northern Chile), Tectonics, 23 , TC4004, doi:10.1029/2003TC001519.

Walcek, A. A., and G. D. Hoke (2012), Surface uplift and erosion of the southernmost Argentine Precordillera, Geomorphology, 153-154, 156-168, doi:10.1016/j.geomorph.2012.02.021.
Whipple, K. X. (2001), Fluvial landscape response time: How plausible is steady-state denudation?, Am. J. Sci., 301, 313-325, doi:10.2475/ ajs.301.4-5.313.

Whipple, K. X. (2009), The influence of climate on the tectonic evolution of mountain belts, Nat. Geosci., 2, 97-104, doi:10.1038/ngeo413.

Whipple, K. X., and G. E. Tucker (1999), Dynamics of the streampower river incision model: Implications for height limits of mountain ranges, landscape response timescales, and research needs, J. Geophys. Res. Solid Earth, 104, 17661-17674, doi:10.1029/ 1999JB900120.

Whipple, K. X., and G. E. Tucker (2002), Implications of sediment-fluxdependent river incision models for landscape evolution, J. Geophys Res. Solid Earth, 107(B2), 2039, doi:10.1029/2000JB000044.

Whipple, K. X., G. S. Hancock, and R. S. Anderson (2000), River incision into bedrock: Mechanics and relative efficacy of plucking, abrasion, and cavitation, Geol. Soc. Am. Bull., 112, 490-503, doi:10.1130/0016-7606 (2000) $112<0490:$ RIIBMA $>2.3$. CO 2 .

Whittaker, A. C., M. Attal, P. A. Cowie, G. E. Tucker, and G. Roberts (2008), Decoding temporal and spatial patterns of fault uplift using transient river long profiles, Geomorphology, 100, 233-242, doi:10.1016/ j.geomorph.2008.01.018.

Willett, S. D. (1999), Orogeny and orography: The effects of erosion on the structure of mountain belts, J. Geophys. Res. Solid Earth, 104, 28957-28981, doi:10.1029/1999JB900248.

Wobus, C. W., G. E. Tucker, and R. S. Anderson (2010), Does climate change create distinctive patterns of landscape incision?, J. Geophys Res. Earth Surf., 115, F04008, doi:10.1029/2009JF001562.

Wörner, G., D. Uhlig, I. Kohler, and H. Seyfried (2002), Evolution of the West Andean Escarpment at $18^{\circ} \mathrm{S}$ (N. Chile) during the last $25 \mathrm{Ma}$ : Uplift, erosion and collapse through time, Tectonophysics, 345, 183-198, doi:10.1016/S0040-1951(01)00212-8.

Wu, S. L., R. L. Bras, and A. P. Barros (2006), Sensitivity of channel profiles to precipitation properties in mountain ranges, J. Geophys. Res Earth Surf., 111, F01024, doi:10.1029/2004JF000164.

Yanites, B. J., and G. E. Tucker (2010), Controls and limits on bedrock channel geometry, J. Geophys. Res. Earth Surf., 115, F04019, doi:10.1029/ 2009JF001601.

Yanites, B. J., G. E. Tucker, K. J. Mueller, and Y.-G. Chen (2010), How rivers react to large earthquakes: Evidence from central Taiwan, Geology, 38, 639-642, doi:10.1130/g30883.1.

Zaprowski, B. J., F. J. Pazzaglia, and E. B. Evenson (2005), Climatic influences on profile concavity and river incision, J. Geophys. Res. Earth Surf., 110, F03004, doi:10.1029/2004JF000138. 